\title{
Prospective Aid and Indebtedness Relief: A proposal
}

\author{
by
}

Lode Berlage, Danny Cassimon,

Jacques Drèze and Paul Reding ${ }^{\square}$

First version : January 2000

This version : May 2000

\footnotetext{
- The authors are, respectively, affiliated to the departments of economics of the following universities: KU Leuven, Leuven (lodewijk.berlage@econ.kuleuven.ac.be ); UFSIA, Antwerpen (danny.cassimon@ufsia.ac.be ) ; UCL, Louvain-la-Neuve (dreze@core.ucl.ac.be) ; FUNDP, Namur (paul.reding@ fundp.ac.be). Paper presented at the interdisciplinary colloquium on "Which Debt Relieffor the Third World?", Louvain-la-Neuve, February 11-12, 2000.
} 


\section{Contents}

\section{Part I : General presentation}

1. Human development and debt overhang

2. Three premises

3. Prospective aid

3.1 A trust fund for human development

3.2 Implementing the DAC targets

3.3 The broad accounting picture

4. Debt sustainability and relief

4.1 Defining sustainability

4.2 Interpretation and implementation

5. Governance, conditionality and implementation

5.1 Governance and conditionality

5.2 Implementation

\section{Part II : Detailing the main issues}

1. An effort targeted at poor countries

2. Debt relief

2.1 The commitment to cancel the 49 countries' external debt

2.2 Reducing a country's debt service to a sustainable level

2.3 Contribution of resources freed by debt reduction to human development goals

3. Implementing the 2015 DAC targets: how far can we get?

4. Burden sharing between rich countries

5. Making the Initiative work.

5.1. Organisational structure

5.2. Conditionality

6. Relation to the literature on debt reduction

6.1. Rationale and pitfalls of debt reduction

6.2. A multilateral approach to debt reduction

6.3. Debt reduction and aid

\section{Tables 1 to 5}

\section{References}

\section{Acronyms}




\section{Part I: General Presentation}

\section{Human development and debt overhang}

The Development Aid Committee (DAC) of OECD has formulated in 1995 and updated repeatedly $\amalg_{\text {an }}$ "effort of World partnership for development", with in particular the following targets for the year 2015:

- reduce by half the number of persons with an income less than one US \$ per day

- make primary education universal

- reduce infant mortality by two thirds.

Such a program is unquestionably needed to meet primary needs of human development: basic education, health including reproductive health, nutrition, sanitation. It would require an increase in aid, in particular in Official Development Assistance (ODA), by several tens of billion dollars a year. Yet, ODA is on a downward trend. It fell in 1998 to .24 of $1 \%$ of rich countries' GDP, down from the earlier .45 of $1 \%$ and far from the repeatedly endorsed target of .7 of $1 \%$.

At the same time, debt overhang imposes sizeable transfers of resources from poor to rich countries. Multilateral institutions (the IMF and World Bank) recognise that debt service limits the ability of Highly Indebted Poor Countries (HIPC) to meet basic human development needs. The HIPC initiative, recently extended into the Cologne initiative, aims at bringing back debt service of the poorest countries to more sustainable levels, for the benefit of human development. Civil society organisations, NGO's and religious groups, stress that these initiatives remain grossly inadequate. They plead for a drastic gesture in year 2000, the "Jubileum": either outright debt cancellation, or a new concept of debt sustainability reflecting squarely the ability to meet basic human development needs.

The present paper outlines a proposal that integrates the DAC, HIPC and civil society initiatives into a 15-year program for implementing the DAC targets while resolving fully the debt overhang problem, for a set of 49 poor countries. The proposal requires additional contributions from 23 rich countries amounting to .1 of $1 \%$ of their GDP over each of the 15 years. Although only a small part of the effort would take the form of debt cancellation, the outstanding debt of the 49 poor countries would be totally extinct by year 2015. Hopefully, the DAC targets could be realised by then.

\section{Three premises}

Our proposal draws freely on constructive ideas emanating from civil society organisations or incorporated in the HIPC initiative. It extends these ideas in three directions.

First, the concern for human development applies to poor countries, not only the highly indebted ones. Accordingly, we add to the list of 41 HIPC, with a total

\footnotetext{
${ }^{1}$ See in particular OECD/DAC (1996).
} 
population of 589 million, the other countries with a Human Development Index lower than .5 in 1997. This adds eight countries, bripging the combined set to 49 countries, with a total population of 853 million (in 1997). These 49 countries have on average an annual per capita income of US $\$ 372$, an infant mortality rate of 150 per thousand and a primary school enrolment ratio of $60 \%$. A substantial fraction of the population is living in absolute poverty. Of the 49 countries 37 are in Sub-Saharan Africa.

Second, we turn for funding to a set of 23 rich countries (the US and Canada, Japan, Western Europe, Australia and New Zealand), with a total GDP of 22.000 billion US \$ (1998) and a total population (today) of 846 million. Per capita annual income in these countries, some 26.000 US $\$$, is nearly 80 times as high as in the 49 poor countries. Per capita spending on health or primary education is nearly 100 times as high.

The effort solicited from these countries is not directly related to their holdings of LDC debt. We suggest that the contribution of each rich country consist of two roughly equal parts: a flat contribution equal to .05 of $1 \%$ of GDP, and a variable contribution proportional to the gap between their current ODA outlay and the reference target of .7 of $1 \%$ of GDP; the second component also amounts on average to .05 of $1 \%$ of GDP, bringing the total to .1 of $1 \%$. But we invite the rich countries to include as part of their contributions the debt instruments in their possession, accepting these at a realistic economic value. These two suggestions aim at sharing the burden fairly.

It is difficult to assess precisely how far the proposed contributions (roughly 22 billion US \$ per year during 15 years) could go towards permitting implementation of the DAC targets. The 1997 «Human Development Report» referred to 40 billion US \$ per year world-wide. Our set of 49 countries concerns only some $20 \%$ of the total population of 4 billion mentioned there - but the needs are greater in the poorer countries. The CAFOD paper by Northover et al. (1998) refers to an annual expenditure of US \$ 28 per person, i.e. US \$ 23.5 billion for 840 million persons, which is very close to our proposal, thus confirming grossly its order of magnitude (though coverages are not identical).

The proposed addition to ODA may be given an alternative justification, linked to the "20/20 Initiative" endorsed by UNDP. That initiative aims at earmarking for primary needs of human development $20 \%$ of public revenue in poor countries as well as $20 \%$ of ODA. If ODA were raised from the current level (.24 of $1 \%$ of GDP) to the target level (.7 of $1 \%$ ), and $20 \%$ of the increment were allocated to primary needs of human development, this would release additional resources amounting to $.2 \times .46=$

\footnotetext{
${ }^{2}$ See footnote 21 below.

${ }^{3}$ A more detailed and country-specific calculation appears in part II.

${ }^{4}$ The concern to treat fairly both poor and rich countries was central to the CORDA proposal formulated earlier by four Belgian economists, including two of us; see Drèze et al. (1991).

${ }^{5}$ Neither objective is currently achieved: UNDP et al (1998) estimates that developing countries on average spend about $13 \%$ of their national budget on basic social services while roughly $10 \%$ of ODA is going to these sectors.
} 
$.092 \approx .1$ of $1 \% \$$ of rich countries' GDP; namely the very amount which our proposal mobilises for the same purpose.

It is an unplanned coincidence that the total population of our 49 poor countries is precisely equal to that of our 23 rich countries; the coincidence led us to choose a title with acronym PAIR: we are proposing to "pair up" each citizen of a rich country with a citizen of a poor country, expecting the former to contribute each year one and a half to two hours of earnings towards covering basic human needs of the latter.

Third, we propose a 15-year firm program, fully funded from the start, for implementing the DAC targets and extinguishing in the process the foreign debt of the 49 poor countries. The motivation for this approach is twofold. Regarding the implementation of the DAC targets, the main challenge is to translate targets and funding into operational programs of education, health or sanitation. These are long-run programs. It is recognised that such programs require planning and continuity, hence steady flows of resources. Regarding debt relief, we explain below why we do not recommend unconditional immediate full cancellation. But we share the view, forcefully expressed by Sachs et al. (1999), that "the instability, unpredictability, and timeconsuming nature of [current] roll-over mechanisms contribute to the incapacity of HIPC governments and the international community to formulate long-term solutions to the pressing social crises in the HIPC countries" Accordingly, we program the extinction of the debt over our 15-year horizon.

It should be obvious that our proposal goes much beyond the present HIPC Debt Initiative. Debt cancellation instead of debt reduction is the ultimate target. Priority is shifted from debt to human development, with the aim of achieving for all poor countries, indebted or not, the DAC goals accepted in 1996 by the international community. Compared to the HIPC Initiative, a much broader and more firmly committed effort is expected from ODA donors. Also, we stress below that the proposal should be implemented in a multilateral framework in which- more so than is presently the case- all interested parties are represented and have an effective voice.

\section{Prospective aid}

In this section we explain the logic and broad functioning of our proposal.

\subsection{A trust fund for human development}

Implementing the DAC targets for the year 2015 will require an increase in resources devoted to basic human needs world-wide. In the poorest countries, the additional resources may result from reducing the debt service, from redirection of expenditures (in particular, away from military spending) and from increased aid.

\footnotetext{
${ }^{6}$ A closer link to the "20/20 Initiative" would stand out if the contributions of rich countries were set at $20 \%$ of the gap between their current ODA and .7 of 1\% of GDP. We would easily endorse that modification of our proposal.

${ }^{7}$ Quoted from Executive Summary; see the section entitled “The Current Debt Quagmire" for details.

${ }^{8}$ by approximately a factor of 10: World Bank (1999, table 4), report a total cost, in NPV terms, ranging from $\$ 19$ to $\$ 36$ billion, while our proposal amounts to $\$ 325$ billion.
} 
In the highly indebted poor countries, debt service drains resources away from basic human needs. It would be pointless, counter-productive (as documented by Sachs et al.) and opaque to collect debt service and simultaneously increase aid targeted at basic needs, in the amounts needed to offset the drain of local resources resulting from debt service. Better cancel (outright or over time) any debt, the service of which interferes with the implementation of the DAC targets. This simple principle leads to a definition of "sustainable debt" based upon needs and resources for human development. We explain below how the simple principle gets translated into operational terms.

Putting together the implementation of DAC targets and the cancellation of unsustainable debt leads to the following scheme. The annual contributions of the 23 rich countries, amounting overall to some 22 billion US $\$$ a year, are paid to a Trust Fund (the existing HIPC Trust or a similar institution). This Trust Fund - say the PAIR Fund - acquires as soon as possible all the eligible public and publicly guaranteed debt of the 49 poor countries, offering to creditors a price reflecting a reasonable economic value. That total eligible debt (multilateral, bilateral and privately held) has a Net Present Value of some 183 billion US \$ to which we assign an economic value of some 88 billion US \$. The "economic value" is meant to reflect the present value of what creditors might hope to collect, in the absence of further debt relief (see section 2.1 of Part II.)

The PAIR Trust Fund will thus disburse funds on two fronts: to help implement the DAC targets in the 49 poor countries, and to acquire the outstanding debt of the same countries. Clearly, the more is spent on debt, the less can be devoted directly to human development. That is why only the unsustainable part of the debt will be cancelled outright. The sustainable part, now held by the Pair Fund, will continue to be serviced by the debtor countries, with the proceeds going to the Fund and used towards implementing the DAC targets. (We explain below how we guarantee that service remains sustainable and results in extinguishing the debt at the end of the 15 year horizon.)

This approach, backed by a suitable definition of sustainability, corresponds to an objective of distributive fairness across poor countries. Sustainable debt should be serviced to provide resources for human development in all poor countries, not only the debtor country itself. The approach may also be understood as relieving the set of 49 countries entirely from its debt obligations, for the benefit of human development in the same set of countries. Collectively, all debt is cancelled. The remaining service amounts to redistributive transfers among poor countries.

It should also be noted that cancelling unsustainable debt releases resources for human development in the debtor countries. These resources may help reduce the need for additional ODA towards implementing the DAC targets. In line with the 20/20 Initiative, we assume that $20 \%$ of cancelled amounts are allocated to human development. A significant advantage of our proposal is that the PAIR Trust Fund

\footnotetext{
${ }^{9}$ As explained below, this is the "human development approach to debt sustainability" introduced by several civil society organisations.
} 
would become the single creditor of participating poor countries. Debt relief could thus be based on an overall assessment of the debtor country's situation, which is more difficult under piecemeal negotiations with individual creditors. Also, the burden of negotiations would be reduced drastically.

\subsection{Implementing the DAC targets}

The main challenge emerging from our proposal is the implementation of the DAC targets. The new opportunity - not contemplated so far - is the availability of a budget committed for a 15-year horizon. This is coupled with a coextensive program reducing and maintaining debt at sustainable levels. There is thus scope for defining long-run programs of human development, endowed with continuity and financial sustainability. The next step is to invite poor countries to define their programs, with the assistance of multilateral organisations and NGO's. Such a process is already under way at the initiative of the IMF and the World Bank under the title "Poverty Reduction Strategy Papers" (PRSP); see IMF/IDA (1999b). Our proposal adds the dimension of potential long-run aid flows, which permits more meaningful long-run strategies.

This approach is unquestionably two-edged. Against the merits of a global long run approach, one must be aware of the drawbacks associated with size and scope. We do not advocate setting up yet another administration. We suggest to involve directly the poor countries in the preparation and implementation of their own programs. And we suggest allocating the resources marshalled by the PAIR Fund on a co-financing basis. Hopefully, these two principles may preserve the merits, while minimising the drawbacks. They also underlie the IMF/IDA's "Poverty Reduction Strategy Papers" approach.

The principles guiding the definition of sustainable debt may also be applied to the definition of a country's sustainable levels of expenditures for human development, thereby providing criteria for the amounts to be co-financed ${ }^{0}$. The fact that the PAIR Fund would operate with a fixed global budget constraint also means that the opportunity cost of funds allocated to a particular program in a given country is defined by the use of the same funds in another poor country (at the same or at a later date). Also, programs defined in different countries of the same region may entail externalities, which could be taken into account by the PAIR Fund.

The main initial tasks concern the definition of a governance structure for the PAIR Trust Fund, of priorities for its co-financing activities, and of criteria of conditionality for the participation of poor countries. We deal below with governance and conditionality. As for priorities, they should emerge naturally from the DAC targets. Easier said than done, perhaps. But there exists a lot of valuable research from which to start. It would take us too far afield to expand here.

\footnotetext{
${ }^{10}$ That is, inability to fund adequately basic social expenditures reveals both debt unsustainability and need for co-financing of these expenditures.
} 
Another two-edged aspect is linked to the novelty of the approach. The fact that a multilateral 15 year scheme for funding human development has not been worked out before, in spite of the clear merits of such a global approach, is an argument in favour of our proposal. But the novelty also means that the approach is untested. It would thus be important to monitor performance and to adjust procedures and policies to experience. That part is easy. The early disbursements of the PAIR Fund will be addressed to acquiring the outstanding debt of the 49 poor countries. At the same time, these countries should be involved in defining their human development policies and programs, a process which is already going on in selected HIPC countries. It would seem reasonable to evaluate the operations after, say, five years. One aspect of the evaluation would bear on the quality of the programs up for financing. If there is a lack of valuable programs, the contributions of the rich countries could be temporarily scaled down - while keeping unchanged the long run commitments. For instance, contributions could be geared provisionally to actual expenditures, while the PAIR Fund could continue to commit expenditures up to the limit of committed contributions, i.e., .1 of $1 \%$ of rich countries' GDP.

\subsection{The broad accounting picture}

A very rough accounting of the PAIR Trust Fund operations over 15 years, expressed in present value terms, goes as follows (in billion US \$, at constant prices):

\begin{tabular}{|l|l|l|l|}
\hline \multicolumn{1}{|c|}{ Income } & Expenditures & \\
\hline $\begin{array}{l}.1 \text { of } 1 \% \text { of GDP of } \\
23 \text { rich countries* }\end{array}$ & 325 & $\begin{array}{l}\text { Acquisition } \\
\text { of outstanding } \\
\text { debt }\end{array}$ & 88 \\
\hline $\begin{array}{l}\text { Service of } \\
\text { sustainable debt** }\end{array}$ & 61 & $\begin{array}{l}\text { Funds available } \\
\text { for implementing } \\
\text { DAC targets*** }\end{array}$ & 298 \\
\hline Total & $\mathbf{3 8 6}$ & Total & $\mathbf{3 8 6}$ \\
\hline
\end{tabular}
Assuming discount rate equal to the growth rate of GDP.
$* *$
As per calculations below; very rough estimates.
***
In addition to resources freed by debt cancellation (say, 20\% of (183-61) billion US \$, i.e. 24.4 billion US \$).

To the extent that much of the outstanding debt of the 49 poor countries is held by participating rich countries, the corresponding debt instruments will be transferred to the PAIR Fund, at economic value, in payment of the creditors' annual contributions. The corresponding amounts have not been netted out in the table. (See Part II for the calculation of economic value and for the treatment of debt held by multilateral institutions.)

Needless to say, all these figures are subject to very wide margins of error, the most solid being the GDP of rich countries. We propose establishing the PAIR Trust Fund on the basis of a firm commitment by the rich countries to make contributions for 
15 years at the suggested rate of .1 of $1 \%$ of GDP. The PAIR Fund should then proceed with the acquisition of outstanding debt and appraise for each debtor country which amount of his debt is sustainable and how this remaining debt is to be serviced. The Fund should also cooperate with the poor countries and with official and private development agencies to approve programs and funding towards implementing the DAC targets. After five years, the whole operation should be reviewed and assessed. We suggest redefining at that time a new 15 -year program in the same spirit.

\section{Debt sustainability and relief}

\subsection{Defining sustainability}

Any definition of sustainable debt embodies a value judgement on what is, and what is not, sustainable. For instance, the HIPC initiative now defines a ratio of net present value of debt (NPV) to exports in excess of $150 \%$ as unsustainable. That is a value judgement: why not 100 or $300 \%$ ? Introducing such a judgement is inescapable. Making it explicit is a virtue.

Our definition of sustainable debt similarly calls for value judgements, that we make explicit and offer to debate. The approach is not new. It is borrowed from various civil society proposals, as also summarised in IMF/IDA(1999a), and expressed sharply in a CAFOD paper by Northover et al. (1998). Our own contribution resides in applying the principle first in the year 2001 and then prospectively over the next 15 years, so as to guarantee that future debt service remains continuously sustainable and that all outstanding debt is extinguished by the year 2015. Also, under our proposal, remaining debt service is paid to the PAIR Fund and is thus recycled towards human development.

The approach works as follows. Define for each country, by means of objective criteria, a tax-revenue base; applying to that base a standard-tax rate yields the country's standard revenue; next, deduct from that standard revenue an allowance for basic human needs (a flat dollar amount per capita times population); the outcome of the calculation (which may be positive or negative) is a "net feasible revenue", available to meet other public expenditures and/or debt service. (Relying on an exogenous tax rate and an exogenous allowance for basic human needs, independent of the country's policies, minimises the problem of moral hazard.)

Clearly, when the "net feasible revenue" is negative, any amount of debt is " unsustainable" and should be cancelled outright. When the "net feasible revenue" is positive, a level of debt is defined as "sustainable" if its service does not exceed an acceptable proportion of that revenue.

The CAFOD suggestion is to define the tax revenue base as consisting only of incomes above the absolute poverty line of US \$ 1 per person per day. Using that definition and proceeding as suggested above leads us to define sustainable debt service as a suitable fraction $c$ of an adjusted national income $Y$-C, whenever the latter is positive. That is:

$$
\text { sustainable debt service }=c \cdot \max [0, Y-C] \text {. }
$$


Of course, the parameters underlying $c$, and $C$ - which can be interpreted as income exempted from debt service - need to be agreed upon. That calls for further research. Under the CAFOD proposal, $c=.05$ and $C=$ sum of incomes below poverty line + [US $\$ 28 \times$ population)/ tax parameter]. In section 2.2 of part II, we select $c=$ $1 / 15$ and $C=0.7 Y$ 11. Also, some improvements of the formula are possible - for instance increasing both $c$ and $C$ at constant present value would increase progressivity. We omit details here.

\subsection{Interpretation and implementation}

Formula (1) with a fixed $\mathrm{C}$ is analogous to an income tax formula, where earned income $Y$ is reduced by an exemption $C$ before being taxed at the constant rate $c$. There is, however, a hidden element of progressivity. Indeed, the sum of incomes below the poverty line is apt to be inversely related to $Y$, for a given population; accordingly, as per capita income increases, the per capita exemption decreases and sustainable debt service increases relative to income. A more pronounced degree of progressivity could be introduced by allocating to debt service a fraction of net feasible revenue that increases with per capita income

Formula (1) is also comparable to that applicable in some countries to withholdings from earned income on behalf of creditors. For instance, in Belgium, creditors may solicit court decisions that mandate employers to withhold from wages or salaries an amount directly transferred to creditors of an insolvent employee. The withholding is limited to a fraction (here $c$ ) of income in excess of a subsistence level (here $C$ ). If our formula were applied, it would be equivalent to an extension of bankruptcy provisions to international country debts. Several civil society organisations advocate that extension.

Discounting at the rate of real GDP growth and using an amortisation period of 15 years, sustainable debt is equal to 15 times annual sustainable debt service.

Any debt exceeding the sustainable ceiling so defined is cancelled outright. In each year $t$ from 2001 to 2015, sustainable debt service is calculated by formula (1) applied to current data, and is collected by the PAIR Fund. In year 2015, the debt is extinguished, irrespective of the actual amount of service collected. If outstanding debt is lower than the sustainable ceiling, no debt is cancelled, but it is still desirable to organise the debt service to the Fund according to formula (1), so as to provide insurance to the debtor country.

\footnotetext{
${ }^{11}$ Applying the CAFOD parameters (including a value of .25 for the standard tax parameter) to aggregate figures for the 49 countries combined (with $Y$ per capita $=\$ 372$ and assuming that $25 \%$ of income is not taxable) suggests an order of magnitude of 7 billion US \$ per year for sustainable debt service ; with the parameter values selected in section 2.2 of part II $(c=1 / 15$ and $\mathrm{C}=0.7 Y)$, the $\$ 7$ billion become $\$ 6$ billion; this amount is, for the latter parameter values, reduced to some 4 billion $\$$ on the basis of a country-by-country assessment, reflecting the current unequal distribution of external debt among the 49 countries.

${ }^{12}$ This specifies the parameter $c$ in formula (1) as increasing in $(Y-C)$.

13 The annual payment will then be equal to a faction $d$ of sustainable debt service defined by formula (1), with $d$ equal to the ratio between actual outstanding debt and the (higher) sustainable debt ceiling $(\mathrm{d}<1)$.
} 
This way of assessing debt service includes an insurance aspect. If actual income declines, the debt service is automatically reduced; if income rises, the service is increased. The consequence for amortisation of the principal is the same. Because this provision is applied irrespecfive of initial debt levels, the benefit of insurance is extended to all 49 countries 14 .

If a participating country experienced the need of additional borrowing during the period 2001-2015, the same principles should be applied to decide whether the additional debt is sustainable. If not, the country should either turn to the PAIR Fund for additional aid (if justified on human development grounds), or seek to obtain funding with service starting after 2015. The former alternative would in principle be more desirable.

This is our basic proposal for debt relief. It meets the objective of guaranteeing that debt service will remain feasible throughout, and it leads to full extinction of currently outstanding debt by year 2015 . It treats fairly both debtors and creditors.

\section{Governance, conditionality and implementation}

\subsection{Governance and conditionality}

We have outlined a major operation, calling for annual contributions of .1 of $1 \%$ of rich countries' GDP. The operation should be managed by a board representative of all interested parties and potentially helpful advisors. A basic list includes:

(i) the donors, i.e. the 23 rich countries and the multilateral financial institutions (IMF, World Bank, regional development banks)

(ii) the beneficiaries, i.e. the 49 poor countries

(iii) the UN organisations concerned with implementation of the DAC targets (WHO, UNICEF, UNAIDS, WFP, FAO, co-ordinated by UNDP) and DAC itself

(iv) Civil Society organisations (NGO's, religious groups,

(v) the academic community of development researchers. 15

That is a long list. The total number of representatives should be kept small enough to have a functioning body. Something like 25 to 30 members could be elected, with the seats allocated between categories - for instance $1 / 3$ for (i), 1/3 for (ii) and $1 / 3$ for (iii)-(v) combined ${ }^{\text {LG }}$.

The existing HIPC task force could be called upon to organise the debt relief part of the program, according to the principles set forth above, and under the authority of the board.

\footnotetext{
${ }^{14}$ Optimal insurance theory would again suggest increasing the degree of progressivity, by raising simultaneously $c$ and $C$, at unchanged expected value of debt service.

${ }^{15}$ The International Economic Association, A UNESCO-affiliated NGO, could appoint academic representatives.

${ }^{16}$ The decisions of the Board could be prepared and approved annually by a general assembly of all the parties listed under (i)-(v), i.e. some 130 members or so.
} 
The board should direct its immediate attention to eliciting country- or regionlevel programs for implementing the DAC targets. To that end, it should rely on the expertise accumulated in all spheres, i.e. the five spheres represented on the board. Doing so expeditiously will require savoir faire. Guidelines have already been developed under the PRSP approach (see IMF/IDA 1999b), and applied by some countries (like Uganda and Ghana). The idea and spirit of these guidelines parallel our suggestions here and thus provide a natural starting point. Some concern has already been voiced that the current PRSP might not stand up to its high expectations; among other things, it is feared that the process might still not put the government "at the driver's seat" as well as not lead to full involvement of the countries' civil society. We deem it crucial for our proposal that the PRSP spirit also fully materialises in practice.

In turning to the important tasks outlined here, due attention should be paid to the fact that 37 among the 49 beneficiary countries are in Sub-Saharan Africa.

At the same time, the board should define guidelines for the allocation of part of the savings associated with debt cancellation to meet primary needs of human development. (A part equal to $20 \%$ was used above, because congruent with the "20/20 Initiative".) And the board should define the criteria of eligibility for participation in the program (the "conditionality").

Because the program addresses directly the problems of human development, that aspect of conditionality automatically receives center-stage status. Because the program is defined over a 15-year horizon, and its implementation can be suspended whenever conditions are violated, there is no need to introduce unproductive waiting periods.

A broad view of conditionality should combine democratic practices, responsible government, suitable institutions and sound macroeconomic policies. The test of these conditions should be part of the preparation of the PRSP's underlying the Fund's operations. During the colloquium for which this paper was prepared, much insistence was placed by participants on the paramount importance of functioning democratic institutions, both for human development and for effectiveness of ODA. The representative composition of the board is the best basis for translating that principle into operational guidelines.

\subsection{Implementation}

Implementation of our proposal raises a twofold political challenge : Can the proposal pass the test of adoption by the 23 rich countries ? If so, can a 15 year commitment be given credibility?

We are not qualified to suggest the suitable diplomatic avenues to marshal adoption, but we may contribute an important precision. Ours is not a « take-it-or-leaveit » proposal, the merits of which hinge on $100 \%$ adoption. We propose a consistent global approach towards fostering Human Development and eliminating excess indebtedness. Starting from the DAC targets for year 2015 and from a realistic assessment of the debt situation, we propose a budget (see table in section 3.3). It calls 
for annual contributions of .1 of $1 \%$ of rich countries GDP, adding up to US\$ 325 billion, with an up-front firm commitment of US\$ 88 billion for debt buy-back.

We offer two remarks . First, if one were separating the debt problem from achievement of the DAC targets, the budget could be reduced from 325 to 88 billion $\$$. Most of the needed funding would take the form of transferring to the PAIR Fund debt instruments held by the rich countries or multilateral institutions. We would insist on implementing fully at least that part of our proposal. And we note that the 88 billion $\$$ at stake correspond precisely to four annual contributions of .1\% of GDP. Thus, we would insist on full implementation for the first four years, with full debt buy-back.

Second, beyond the first four years, contributions at a rate falling short of the proposed .1\% of GDP would always be welcome, and the best way to use these contributions remains the Pair Fund scheme, in our opinion. If the full contributions cannot be marshalled, one should still maintain the program, collect whatever contributions prove politically feasible and define priorities on the basis of available means. In that case, furthermore, one should invite those countries willing to contribute more than some others to pay their full contributions to the PAIR Fund, possibly with a collective right to earmark these additional contributions for specific uses (either a set of beneficiary countries or a set of thematic programs). (By a collective right, we mean a right to be exercised co-operatively by the set of countries making additional contributions.) In particular, the European Union could organise full contributions by its members earmarked for the ACP countries ${ }^{2}$. That defines our second-best alternative under incomplete funding.

Regarding the 15-year commitment issue, we realise that existing governments are not always able to make credible long-run commitments : there is a time-consistency issue. The naive economist's remark that it could always be done by issuing long-term bonds would only complicate the adoption issue. It was suggested during the colloquium that an international treatise would be an answer. Again, we do not feel qualified to propose the most suitable diplomatic solution. A firm commitment for the initial four years, backed by transfers or firm purchases of debt instruments seems credible as far as these initial years go. We have accepted the principle that the situation be reviewed then, and a new 15-year program defined. If the overall program has been approved, we must (and can) live with the time consistency problem that will arise then. There is little choice. The alternative of giving up the program altogether is clearly inferior.

\footnotetext{
${ }^{17}$ African, Caribbean and Pacific countries associated with the European Union through the Lomé and Suva conventions
} 


\section{Part II : Detailing the main issues}

\section{An effort targeted at poor countries}

Our proposal aims to increase debt relief and aid for poor countries, with a human development perspective. In choosing our set of target countries we have used the following two criteria :

- The HIPC Initiative has identified a set of 41 poor and severely indebted countries. Given that the HIPC Initiative has gained a new momentum in Cologne as well as a clearer focus on human development, it seems natural to include all the Highly Indebted Poor Countries in our set, even those which do not satisfy our second selection criterion which we now explain.

- Human Development is not suitably measured by the sole level of a country's per capita GDP. To select additional countries which can be listed as "poor" in a human development sense, we use the Human Development Indicator (HDI) computed by the United Nations' Development Programme. This indicator takes a broader view of human development than per capita income; it also covers a country's

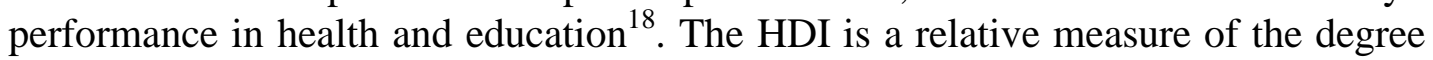
of a country's human development; it may vary over the range from 0 to 1 . We use the latest HDI data , computed for 1997 . We choose to include in our target set all countries which have a 1997 HDI level of 0.50 or less. This defines, according to the 1999 Human Development Report, the countries which belong to the "low human development" category. Of the 35 countries in this category, 27 are also Highly Indebted Poor countries, so that this second criterion for selecting countries covered by our proposal adds 8 non-HIPC countries to our target set $\frac{20}{\text {. }}$

Table 1 displays the list as well as some relevant data for the 49 HIPC and non-HIPC countries included in our set ${ }^{2-}$. Several points are worth noting:

\footnotetext{
${ }^{18}$ The Human Development Indicator (HDI) synthesises three different, equally weighted, aspects of human development : health (measured by life expectancy at birth), education (measured by the literacy rate of adults and the global enrolment ratio for all levels of education) and income (measured as GDP per capita, at purchasing power levels). Income is included in the HDI as a substitute for all human development aspects other than health and education.

${ }^{19}$ United Nations Programme for Development (1999), Human Development Report. The 1999 data are not quite comparable with earlier data, as the methodology of the index has been refined to account better for differences in income levels.

${ }^{20}$ Note that there are 12 HIPCs which have an HDI level higher than 0.5 and belong to the "average human development" category (with a maximum of 0.701 for Guyana). The total population of these 12 countries amounts to some 220 million, out of 589 million for the 41 HIPC countries.

${ }^{21}$ Some countries may be missing from the sample because of unavailability of relevant data. This is for example the case for Afghanistan (pop. 25 million, with life expectancy at birth as low as 45 years as the only HD indicator). Also, there is an inevitable arbitrariness in the $0.5 \mathrm{HDI}$ threshold we have used to select the "poor" countries of our sample. For example, the following four "average human development" countries would have been added to the sample if we had taken a $0.55 \mathrm{HDI}$ level as threshold : Comoros, Pakistan, Cambodia and India (with total population of 1.1 billion and an external debt of \$101 billion NPV).
} 
- Nigeria which had for some time been included in the HIPC list before being excluded (while Malawi was added) is part of our target set, on account of its low HDI level $(0.456)^{22}$.

- Total population in our setis 840 million (of which $69 \%$ in HIPC countries). The average HDI level is $0.451^{\mathrm{E} 3}$, ranging from 0.254 (Sierra Leone) to 0.701 (Guyana). Ayerage 1997 per capita income level is \$372, with a maximum of \$ 970 (Bolivia) 24. Average infant mortality rate is 148 per 1000 , about 11 times the level observed for high income countries 5 . For the countries for which data are available, net enrolment in primary school ratios range from 25 (Mali) to $100 \%$ (Malawi), with an average of $59 \%$.

- Net Present Value of Debt (NPV) for the 49 countries amounts to $\$ 195$ billion ( $\$ 230$ per capita), of which HIPC countries are responsible for $80 \%$ (\$270 per capita). Note that non-HIPC Nigeria has the highest absolute NPV of debt (\$27 billion, \$270 per capita, $13.8 \%$ of the set' s total debt), the Republic of Congo the highest per capita level ( $\$ 4.5$ billion, $\$ 1660$ per capita).

- Total grants to the countries in the set amounted in 1997 to \$ 13 billion, slightly more than total debt service the countries have paid. However we observe an asymmetry between HIPC and non-HIPC countries. For the former, grants exceed debt service by $33 \%$, while for the latter they fall short of debt service by $25 \%$. Aid flows seem to be somewhat biased in favour of HIPC countries. Indeed, for some of them Official Development Assistance (ODA) flows represent a huge proportion of their GDP (up to 68\% for Guinea-Bissau and 60\% for Mozambique).

\section{Debt Relief}

In order to enable the countries in our set to achieve the DAC 2015 human development goals, our proposal provides for a major aid effort which includes comprehensive debt relief. The debt relief we envisage has two characteristics : (1) collectively, the debt of the 49 countries is cancelled ; (2) individually, a country's debt is reduced to a sustainable level and the remaining debt service is paid to the PAIR Trust Fund. Also, target countries are expected to use a fraction of the resources previously used for debt service to improve human development of their people. We briefly discuss each aspect.

\footnotetext{
${ }^{22}$ Sachs and al. (1999) also argue that Nigeria should be included in the group of countries selected as target for a comprehensive debt reduction scheme.

${ }^{23}$ Average HDI level for "high human development" countries is 0.904

${ }^{24}$ Current dollars, GNP computed with three year average \$ exchange rates, not adjusted for divergences in PPP (World Bank Atlas data). The corresponding average GDP per capita amount for high income countries is \$ 25,700 .

${ }^{25}$ Source : World Bank, World Development Report 1998-1999.
} 


\subsection{The commitment to cancel the 49 countries' aggregate external debt}

Cancellation of the 49 countries' total external debt is a necessary contribution to an international effort to help these countries reach their human development goals within a 15 year horizon. Indeed, it does not make economic sense for rich countries to disburse aid to the target group of poor countries and at the same time to collect debt service from them ${ }^{26}$. A commitment from rich countries to extinguish the 49 countries' total external debt over a 15 year horizon is therefore expected. Rich countries will make sure that all the claims held by creditors on the group of poor countries be transferred to the PAIR Trust Fund. In this way the PAIR Fund becomes the sole creditor of the 49 countries in the target set. It is known from the start that any debt service to the Fund will become available to the pool of 49 countries, to help them achieve the 2015 Human Development goals. Individually, each country will continue to pay debt service on the sustainable fraction of its initial debt (see 2.2).

Combining individual debt reduction with collective cancellation achieves a desirable balance between the aim of alleviating the plight of all poor countries and the objective of fairness amongst them ${ }^{27}$.

We now define the external debt which is eligible for cancellation and discuss the budgetary cost for rich countries.

The debt eligible for total cancellation for the sample countries as a group is the long term, public or publicly guaranteed debt (PPG), outstanding and disbursed (DOD), with respect to official (bilateral and multilateral) as well as private creditors. The eligible debt also includes interest arrears on long term debt as well as the use of IMF credit. However, it does not include private debt which is not publicly guaranteed nor short term PPG debt due to private creditors. Table 2 gives detailed data on the face value of eligible and non-eligible debt. We assume in this table that all interest arrears are short term debt with respect to official creditors. Short term debt held by private creditors, which represents less than $5 \%$ of total debt stocks at face value, is not considered eligible. Its cancellation would be counterproductive as it would undermine the country's normal foreign trade operations. Eligible debt represents, for the group of 49 countries, $94 \%$ of total outstanding PPG Debt.

The budgetary cost to rich countries of the cancellation of eligible debt is estimated in the following way. The total debt eligible for cancellation has a net present value (NPV) in 1997 of $\$ 183$ billion. However, the actual costs, i.e. the funds which need to be raised by new budgetary appropriations, can be estimated to be much lower. This is

\footnotetext{
${ }^{26}$ For middle-income severely indebted countries, debt reduction (e.g. Brady deals) has been advocated as being beneficial for both debtors and creditors because it restores appropriate incentives for adjustment and development. For poor countries, the case for large scale debt reduction and possibly cancellation is much stronger, as debt service is clearly an obstacle to achieving a basic, minimum level of human development.

${ }^{27}$ Outright cancellation is unfair to countries which have a low level of external debt, while being equally poor and underdeveloped. It favours countries which have had an easy access to borrowing abroad, possibly on the basis of their wealth in natural resources, or even countries which have grossly mismanaged their economy. Another argument against outright cancellation is moral hazard. Highly indebted countries which benefit from unconditional debt cancellation may be induced to adopt less disciplined policies and to lapse again into their old habits of domestic mismanagement, in the expectation that future debt cancellation will again erase their tab. Although external shocks are responsible for a huge part of the poor countries' debt build-up, this moral hazard argument cannot be discounted altogether. The proposed framework keeps this risk at a minimum.
} 
so because this NPV figure is computed under the hypothesis that the debt will be fully serviced 28 . This is obviously a quite unrealistic hypothesis and has been recognised as such both by official and private creditors. Creditors can therefore be expected to have made for many years the necessary provisioning on their balance sheet in order to reflect the declining true economic values of these assets. The actual write-off of the debt from its NPV to its economic value should then be considered as a balance sheet clean-up operation. As such, it does not need new budgetary appropriations from official creditors nor additional provisions on current profit and loss accounts for private creditors ${ }^{2}$. Beyond this general principle, it is however necessary to distinguish between bilateral and multilateral creditors and between concessional and nonconcessional debt. Table 3 gives, country by country, the detailed estimates, on the basis of various hypotheses briefly discussed hereafter.

- We postulate that debt held by the Bretton-Woods multilateral institutions (IMF, World Bank and affiliated institutions) has fo be valued at full NPV, given the particular seniority status of these creditors ${ }^{20}$. Given the unavailability of detailed published data, we postulate that, for non-concessional debt, NPV is equal to face value. This allows us to estimate NPV of concessiopal debt from the reported NPV of total (concessional and non-concessional debt) ${ }^{2}$. The amount necessary to compensate the multilateral creditors is estimated at $\$ 55$ billion (21 for nonconcessional and 34 for concessional debt).

- For bilateral official creditors, the residual economic value is put at $30 \%$ of NPV for non-concessional debt and at $15 \%$ for concessional debt ${ }^{22}$. Most of this debt is held by the rich countries, although some might need to be bought back from other official creditors, in which case a "pari passu" discount would be applied. The total cost of acquiring the debt held by bilateral official creditors is estimated at $\$ 25$ billion ( $\$ 20$ billion for non-concessional and $\$ 5$ billion for concessional debt).

- A small amount of eligible long term debt is held by private creditors. Taking the somewhat optimistic view these creditors agree on a "pari passu" effort, we apply a buy back value of $30 \%$ to their claims, to get a cost of $\$ 8$ billion.

\footnotetext{
${ }^{28} \mathrm{NPV}$ is lower than face value whenever the interest rate to be paid on the debt is lower than the interest rate used to compute the present value for each future payment. NPV will therefore be lower than face value whenever the debt is on concessional terms. Note that exchange rates may also give rise to a wedge between face value and NPV.

${ }^{29}$ Transferring debt instruments to the PAIR Fund at their economic value may necessitate new budgetary appropriations for those creditors who did not make the necessary provisioning for non performing debt claims. Nevertheless the PAIR Fund should not impute to their debt instruments a higher value than the economic value imputed to other creditors' debt instruments. Doing so would not only imply transfers from creditors who were prudent enough to provision to those who were not, but also unfair transfers from weakly to heavily exposed creditors.

${ }^{30}$ Evaluation of multilateral debt at $100 \%$ of NPV is conservative, as it abstracts from the bad loans provisions which have been constituted and could now be mobilised. Also, use of IMF gold (outright sales or other revenue raising operations based on it) could provide additional resources and lower the budgetary cost to rich countries. Ultimately however, the precise combination of write-downs and cash compensation will clearly be the outcome of a political negotiation process.

${ }^{31}$ This is equivalent to assigning any divergence between total debt's NPV and face value exclusively to its degree of concessionality.

${ }^{32}$ Note that the data refer to 1997 . Since then, several official creditors have taken steps to reduce or cancel significant parts of these debts.
} 
Adding up, the total extra budgetary cost of acquiring the 49 countries' total eligible external debt, with noffurther service accruing to the creditors, is equal to $\$ 88$ billion, close to $50 \%$ of NPV ${ }^{33}$. (This also means that a total amount of $\$ 95$ billion is written off, at the expense of the creditors, independently of their contributions to the PAIR Fund). This is the amount the rich countries need to commit to fund the debt side of the proposal. It is not really necessary for this amount to be made available up-front. In order to enable the PAIR Fund to organise the buy back, rich countries could simply commit for the future the necessary resources for the Fund to service the outstanding debt, after appropriate renegotiating and rescheduling with the creditors. The Fund would in effect immediately take over all the debt commitments of the 49 countries, while becoming at the same time their single creditor. Contributions to the Fund by rich countries could be made in hard cash or by bringing in their own eligible claims, as valued above, i.e. at a realistic economic value $\mathrm{e}^{4}$.

\subsection{Reducing a country's debt service to a sustainable level}

Any definition of sustainability is arbitrary. For instance, HIPC II (after Cologne) basically uses a capacity-to-pay viewpoint on sustainability and defines a ratio of net present value of debt (NPV) to experts in excess of $150 \%$ as unsustainable, coming down from $200-250 \%$ under HIPC $\mathrm{I}^{\mathrm{k}}$.

In our definition of sustainable debt, we rely on a proposal made in a CAFOD paper by Northover et al. (1998). As mentioned in part I, we

(i) apply the principle first in year 2001

(ii) make sure that it remains applicable for the next 15 years, so as to guarantee that future debt service remains constantly sustainable

(iii) make sure that all debt is extinguished at the year 2015.

The approach works as follows. Define for each country, by means of objective criteria :

the tax-revenue base, $Y-A$, where $Y$ is e.g. GDP and $A$ is non taxable income. The CAFOD proposal suggests to take as $A$ all incomes below the poverty line of $\$ 1$ a day.

the standard revenue, $=a$. $(Y-A)$, obtained by applying to $Y$ the standard-tax rate $a$ the " net feasible revenue" $=$ standard revenue $-B$, where $B$ is an allowance for basic human needs ; net feasible revenue measures the government resources which are available to meet other public expenditures, including debt service.

\footnotetext{
${ }^{33}$ Note that the a large part of these $\$ 88$ billion are concentrated on a limited number of countries : the 8 "costliest" countries represent a share of $50.5 \%$ (Nigeria, Bangladesh, Vietnam, Sudan, Côte d'Ivoire, Congo Dem. Rep., Ethiopia and Zambia, by decreasing order). A $70 \%$ share is reached by just including 7 additional countries for which the individual cost is in excess of $\$ 2$ billion.

${ }^{34}$ Implicitly, this also calls for changing the current OECD/DAC rules whereby debt reduction is included in the ODA statistics at full nominal value. Currently, this rule can result in countries contributing (too) much ODA in the form of debt reduction in order to boost ODA figures without doing much in real economic terms.

${ }^{35}$ The Debt/export threshold takes the availability of foreign exchange as the main constraint for debt sustainability. The HIPC initiative also handles an additional sustainability threshold which is defined in terms of government revenue (the "fiscal window"). Countries may qualify for the Initiative if their (Debt $\mathrm{NPV}) /($ government revenue) ratio is larger than $250 \%$ (provided an openness criterion and a minimal "revenue effort" threshold ratio are met).
} 
When the "net feasible revenue" is negative, any amount of debt is " unsustainable" and should be cancelled outright. When the "net feasible revenue" is positive, sustainable debt service is defined as :

sustainable debt service $=b$. net feasible revenue, where $b$ is the acceptable proportion of net feasible revenue to be devoted to debt service.

Therefore,

sustainable debt service $=(b . a)(Y-A)-b B$

$$
\begin{aligned}
& =(b . a) Y-[(b . a) A+b B] \\
& =c Y-C^{*} \\
& =c(Y-C)
\end{aligned}
$$

where $c=b \cdot a, C^{*}=b \cdot a \cdot A+b \cdot B$ and $C=C * / c$. Of course, this may result in a negative figure, if the allowance for basic needs exceeds standard revenue. As such, the final formula is a definition of sustainable debt service $(S D S)$ as a suitable fraction $c$ of an adjusted national income $Y-C$, whenever the latter is positive. That is:

$$
S D S=c . \max [0, Y-C]
$$

Our debt relief and service scheme works as follows, for any one of the 49 poor countries:

(i) Compute net feasible revenue. If negative, the country's debt is cancelled outright. If positive, calculate sustainable debt service $S D S$ by formula (1) and go to (ii).

(ii) Multiply calculated $S D S$ by 15 to obtain the net present value of debt that will be amortised in 15 years by that $S D S$ (using a real discount rate equal to the rate of growth of real GDP). Compare the result with the country's NPV of outstanding debt (call it NPV), and retain the lower of the two figures. Call it $N P V^{*}$. The corresponding debt service, $S D S^{*}$, is equal to $N P V^{*}$ divided by 15 . Go to (iii).

(iii) If $S D S^{*}=S D S$ as given by formula (1), it is by construction equal to $c(Y-C)$. The country benefits from a debt reduction equal to the difference between NPV and $N P V^{*}$. For the next 15 years, the country will transfer each year $t$ to the PAIR Trust Fund an amount equal to

$$
\operatorname{SDS}_{t}^{*}=c \max \left[0, Y_{t}-C_{t}\right]
$$

At the end of the 15 years, no further service will be required on the initially outstanding debt. That debt will be extinct.

(iv) If $S D S^{*}<\mathrm{SDS}$, the country does not benefit from a debt reduction since its outstanding debt is sustainable. However, it is still desirable to let the country benefit from the embedded insurance mechanism. Define $d=N P V^{*} / \mathrm{NPV}$ (=SDS*/SDS), with $d<1$. The country's annual service will then be:

$$
S D S^{*}=d \cdot c \cdot \max \left[0, Y_{t}-C_{t}\right] .
$$


Again, no further service will be required after year 2015 .

If a participating country experienced the need of additional borrowing during the period 2001-2015, the same principles should be applied to decide whether the additional debt is sustainable. If not, the country should either turn to the PAIR Fund for additional aid (if justified on human development grounds), or seek to obtain funding with service starting after 2015. The former alternative would in principle be more desirable.

Further research should determine the optimal values for the parameters $\mathrm{c}$ and $\mathrm{C}$, and check the consequences of minor adjustments to the basic formula (1). It is beyond the scope of this paper to make detailed country-by-country estimations of debt relief according to the mechanism described here, basically because of current lack of publicly-available and reliable country-specific data on some of the parameters needed to make the estimations

In the meantime, to assess the order of magnitude of the amount of debtor country debt reduction, the following approximation is suggested.

We again start from the principle that eligible debt be cancelled after 15 years. Assuming that the real interest rate, to be used as discount rate, is the same as the real growth rate of GDP, an annuity of $\mathrm{x} \%$ of GDP has a present value of $15^{*} \mathrm{x}^{*} \mathrm{GDP}_{0}$, where $\mathrm{GDP}_{0}$ is initial GDP. Suppose one places a ceiling $x^{C}$ on $\mathrm{x}$, i.e. on total debt service (TDS) as $\%$ of GDP during the 15 years envisaged in the PAIR-Fund initiative; this is then equivalent to a cejling on NPVdebt/GDP $\mathrm{G}_{0}$ equal to $15^{*} x^{C}$. All debt higher than this ceiling is cancelled ${ }^{\text {kz }}$.

What would be a fair value for the threshold (maximum) NPVdebt/GDP ratio for our set of countries? In other words, what would be a sustainable NPVdebt/GDP ratio? Although both ratio's are not fully comparable, as a starting point it might make sense to remember that for rich Western-European countries to be eligible for membership of the European Monetary Union, the ceiling Debt/GDP ratio was set at 60\%. Clearly, it would be excessive to submit our set of poor highly-indebted countries to the same rigour, so this $60 \%$ Maastricht ratio would be too high. In Table 4, we select a threshold ratio of $30 \%$, i.e. halving the Maastricht ratio ${ }^{8}$. Whereas this ceiling is applied to total PPG debt, cancellation occurs only on eligible debt. Under this scenario, total remaining debt to be serviced amounts to $\$ 61$ billion, implying a sustainable annual debt service of $\$ 4$ billion. Correspondingly, total debt reduction is equal to $\$ 122$ billion in NPV. The table also includes country-specific details of the amount of debt relief under this scenario. Additionally, simulations show that sustainable debt increases to $\$ 79$ billion (\$111 billion) if a threshold ratio of $40 \%(60 \%)$ is selected $\frac{\text { Bg }}{\text {. }}$.

\footnotetext{
${ }^{36}$ While recent global and regional data e.g. on the number of people living beyond $\$ 1$ a day and on the poverty gap are publicly available (see e.g. World Bank, 1999), country-specific data are not. Some of the required data are a subject of research under way within the framework of the World Bank's forthcoming World Development Report 2000/01 on poverty.

${ }^{37}$ Note that this procedure puts, in formula $(1), \mathrm{c}=1 / 15$ and $\mathrm{C}=(1-\mathrm{xC}) \mathrm{Y}$.

${ }^{38}$ This implies $\mathrm{x}^{\mathrm{C}}=0.3 / 15=0.02$, and therefore $\mathrm{c}=1 / 15$ and $\mathrm{C}=0.7 \mathrm{Y}$ in formula (1).

${ }^{39}$ The corresponding values are $0.027(0.04)$ for $\mathrm{x}^{\mathrm{C}}$ and $0.6 Y(0.4 Y)$ for $C$ in formula (1).
} 


\subsection{Contribution of resources freed by debt reduction to human development goals}

As an element of conditionality and to optimise the human development impact of debt relief, it seems fair to link freed resources to additional human development spending. This link is also explicitly used in the current HIPC framework. A common approach is to use a (local currency) counter-value fund, as is done in most so-called debt for development swaps.

In line with the argument exposed in the 20/20 Initiative ${ }^{0}$, we suggest that $20 \%$ of the NPV of debt relief be used by the country as an increase in budgetary spending for basic social services. Using the results of the previous section, corresponding to a debt relief of 122 billion USD in NPV, this $20 \%$ would amount to about 24.4 billion USD, to be added in the PAIR Fund balance sheet as additional income, available for human development. This can be seen as another way of burden sharing of additional resources between (different types of) creditors and the debtor country. It is to be used by the country itself as a direct increase in its social spending instead of through a separate framework outside the official government budget. In some countries, more than $20 \%$ of the amount of debt relief could well be earmarked for basic social services, and this possibility should be kept in mind when drawing country-level arrangements.

\section{Implementing the 2015 DAC targets : how far can we get ?}

Our proposal to a commitment of increasing ODA by .1 of $1 \%$ would amount to roughly 22 billion US \$ per year during 15 years, or a total of about 325 billion US \$ in NPV (using again the real GDP growth rate as interest rate). Taking into account additional income from remaining debt service by the debtor countries (61 billion US \$) and allowing for compensating creditors for the economic value of debt (88 billion US \$), this would amount to $\$ 298$ billion, directly administered by the PAIR-Fund, plus $\$ 24.4$ billion (local currency equivalent) coming from the resources released from debt service, altogether again about 325 billion US \$ available for additional spending on human development and poverty alleviation purposes in general. How far would that take us towards permitting implementation of the DAC targets?

The 1997 UNDP Human Development Report suggests that an amount of \$ 40 billion per year would necessary for 5 years to achieve adequate coverage of basic needs in all developing countries. This figure refers to 1994 estimates compiled from different sources, based on available data from the early 1990s. The amount covers expenditures for basic education ( $\$ 6$ billion), basic health and nutrition (13 billion), reproductive health for all women (12 billion), and safe water and sanitation ( 9 billion).

Very recently, these estimates were updated within the framework of implementing the 20/20 Initiative, in a joint effort of UNDP, UNESCO, UNFPA, UNICEF, WHO and the World Bank (see UNDP et al., 1998, annex I). The aim was to estimate the cost of universal access to basic social services in developing countries, within the areas of basic public health (including nutrition), essential clinical services, reproductive health

\footnotetext{
${ }^{40}$ That initiative, endorsed by UNDP, aims at earmarking for primary needs of human development $20 \%$ of public revenue in poor countries as well as $20 \%$ of ODA (see also footnote 5).
} 
care and family planning, low-cost water and sanitation and universal primary education. These updated estimates suggest that about \$ 206 to \$ 216 billion are needed annually, over a five-year period, to achieve universal access to these basic services ${ }^{41}$. Since current annual expenditure on basic social services in developing countries can be estimated at around \$ 136 billion, the UNDP et al (1998) calculations estimate the necessary additional five-year effort to be about $\$ 70-80$ billion annually, about twice as high as the earlier estimates. The total additional amount needed to a achieve minimum levels of human development in all developing countries is therefore, according to these estimates, in the \$350-400 billion range.

The funds our proposal makes available over a period of 15 years fall in this range. Indeed, our set of 49 counties covers only about $20 \%$ of the total population of developing countries to which the above estimates apply. However, most of the shortfall in human development should be found in the poorer countries. In addition, the UNDP et al estimates are very conservative : they are based on minimum costs and only refer to basic social services, not to the more broadly defined DAC targets.

Clearly, the fact that the inputs (additional funds) would be available does not guarantee that the outputs (human development) will materialise. Recent research fails to show clear significant links between international aid and improvements in poverty and human development indicators, especially for countries that do not pursue sound macroeconomic policies (see especially Collier \& Dollar, 1998). Neither does it establish a significant causal effect of public social sector spending on the improvement of social indicators (see e.g. Filmer \& Pritchett, 1999, on health spending). Therefore financial injections need to be accompanied by an increase in efficiency of aid and public spending within a sound macro-economic policy and good governance framework (Collier \& Dollar, 1999). It is crucial that the lessons from the past be learned and that the PAIR-Fund mechanism contribute to this by imposing the appropriate type of conditionality (see 5.2. below). Efficiency of aid would be also clearly be increased by the greater policy coherence among donors which can be expected within the PAIRFund, in the management of which all the donors would be jointly involved (see section 5 of part I).

\section{Burden sharing between rich countries}

The total amount to be committed, in our proposal, by the 23 rich QECD countries as additional ODA for the next 15 years is equal, in present value terms $\frac{12}{\text {, }}$ to $\$ 325$ billion, representing for each year an additional average contribution of 0.1 of $1 \%$ of their GDP. Table 5 details the 1998 levels of official development aid for each of the 23 rich OECD countries. It appears that aid efforts, as measured by ODA/GDP ratios, are low on average. The 1998 average of $0.24 \%$ of GDP is indeed still quite far from to the more than three decades old, but repeatedly reaffirmed United Nations target of $0.7 \%$ of GDP. In addition, aid levels vary significantly across countries, with, a maximum of $0.98 \%$ of

\footnotetext{
${ }^{41}$ The document notes that these estimates are very rough figures subject to wide error margins because of lacking data and aggregation ; they represent merely the minimum cost since some elements of basic social services are not included ; the cost implications of e.g. improving the quality of these services have also not been taken into account.

${ }^{42}$ Present values in 1998 \$, computed under the hypothesis of a real rate of discount equal to the rate of growth of real GDP.
} 
GDP for Denmark and a minimum of $0.10 \%$ of GDP for the United States. Three countries are above the UN target. Burden sharing will clearly be a key issue in securing political support for the proposal. While many schemes can obviously be devised, we offer one for illustrative purposes.

Two points are worth considering. First, it seems fair that countries lagging in their aid effort should be invited to catch up and therefore contribute proportionally more. Second, the idea of "pairing up" citizens of rich and poor countries calls for an effort in which all rich countries participate. We therefore devise a combination of two sharing rules, using each one to levy half of the 325 billion. Each rule determines one component of a country's increase in its annual ODA/GDP level. The two components are defined as follows:

- the variable component V: each country is expected to contribute proportionally to the gap between its actual ODA level and the target $0.7 \%$ level. Formally, country $\mathrm{j}$ is expected to catch up each year according to :

$$
\mathrm{V}_{\mathrm{t}+1}{ }^{\mathrm{j}}=\mathrm{A}_{\mathrm{t}+1}{ }^{\mathrm{j}}-\mathrm{A}_{\mathrm{t}}^{\mathrm{j}}=\gamma\left(0.7-\mathrm{A}_{\mathrm{t}}^{\mathrm{j}}\right)
$$

where $A_{t}^{j}$ is the ODA/GDP level (in \%) of country $\mathrm{j}$ in year t. The parameter $\gamma$ is chosen so as to generate half of the $\$ 325$ billion, when applied for 15 years to the set of the 23 rich OECD countries. As shown in Table 5, this is obtained for $\gamma=$ 0.01425 . A country starting with an ODA/GDP level of $0.3 \%$ will be expected to progressively increase its ratio to 0.306 in $2001,0.31$ in $2002 \ldots$ and $0.38 \%$ in 2015; for a country starting from $0.6 \%$, the corresponding figures would be $0.601,0.603$ and $0.611 \%$. For the "average OECD country", starting with $0.24 \%$, the progressively increasing ratio makes for a 15 year average of $0.29 \%$. On average, this corresponds to an increase of $0.05 \%$ of GDP for yearly ODA expenditures.

- a flat increase in the ODA/GDP ratio : each country increases immediately its ODA expenditures by a uniform $0.05 \%$ of its GDP ; this increase in its ODA/GDP ratio is then maintained for the next 15 years. This uniform flat increase raises the other half of the $\$ 325$ billion.

Table 5 shows how this combined sharing rule would affect the relative ODA contributions of the 23 countries $^{43}$. If clearly appears that the G-7 countries will be called upon to shoulder the largest part of this new OECD aid effort $(88.6 \%)$, proportionally more than their GDP weight (85.9\%), but only slightly so. The EU-15 would contribute $34.7 \%$ of the total, proportionally less than its GDP weight (38.5\%).

\section{Making the Initiative work.}

The PAIR Fund will be called upon to administer a substantial amount of funds. In our proposal these funds will result from donor countries' contributions as well as from debt service payments on sustainable debt. These funds will be used to acquire the debt of the 49 low income countries covered by our proposal and to improve human development in those

\footnotetext{
${ }^{43}$ The two sharing rules are applied separately for half the amount to be raised. In other words, as far as the variable component is concerned, the gap between the 0.7 target and the country's actual ODA level is computed without taking into account the flat increase of $0.05 \%$ of GDP.
} 
countries. It is necessary that a decision and organisational framework be set up which has wide support among multilateral and bilateral donors as well as among prospective beneficiary countries. In addition, conditions for obtaining support from the PAIR fund have to be specified.

\subsection{Organisational structure}

In part I we suggested that the final decisions on the use of the PAIR FUND resources be entrusted upon a board which is representative of all interested parties. For the preparation and the execution of the decisions of the board there should be a suitable organisational set-up. Creating a separate and completely new organisation to implement our proposal is not the best solution, as it would imply that no use is made of the services and experience of existing international institutions.

We have suggested that the existing HIPC task force could be called upon to organise the debt relief part of our proposal. Similarly, the administration of the human development window of the Fund could draw on the expertise of both the World Bank (and particularly IDA) and the United Nations Programme for Development (UNDP). The Bank and its regional affiliates have over the recent years increased their focus on poverty reduction and have accumulated a substantial experience in assessing, supporting and monitoring national policies in this field. The United Nations Programme for Development directs its activities towards low income countries, with a focus on poverty eradication ${ }^{4}$, has established a strong network of country offices which facilitates partnerships with local actors and has developed expertise in evaluating human development needs. Finally, the Fund is expected to develop a close collaboration with international as well as local NGO's. These organisations indeed play a larger and larger role in financing and implementing poverty reduction projects ${ }^{45}$, usually work in close contact with the local populations and often act as the voice of the poorest amongst them.

\subsection{Conditionality}

In the 15 year time frame of our proposal, we give a strong priority to the debt alleviation scheme. It should be fully applied as quickly as possible to the set of 49 countries. The PAIR Fund acquires the debt of those countries at its 'economic value', determines the fraction, if any, that is sustainable and monitors the debt service payments on this remaining debt. The monitoring guarantees that the debt remains sustainable, whatever the shocks the country faces. Countries which fulfil their debt obligations, as defined by the PAIR Fund, over the 15 year time horizon following the start of the scheme, will have extinguished their debt by the end of this period. For countries who fail to satisfy their debt service obligations to the PAIR Fund, debt service obligations will continue to exist after the 15 year period. We propose that the conditions countries should fulfil, in order to take part in the debt reduction scheme, be minimal : they should, on the one hand, agree on the rules governing the remaining debt service to the PAIR Fund and, on the other hand, issue a clear and verifiable commitment to recycle part of the savings resulting from cancelled debt service to local human development

\footnotetext{
${ }^{44}$ The other 3 areas of concentration are employment and unsustainable livelihoods; advancement of women; and environmental regeneration.

${ }^{45}$ Indeed, the last Human Development Report (UNDP, 1999) reports that NGOs command a budget of about $\$ 1.2$ billion for project financing in developing countries (excluding transition economies - for which the budget is $\$ 1.4$ billion). NGO's resources are on the rise, while the opposite trend is observed for ODA flows.
} 
projects.

As to access of countries to the human development programs financed by the Fund we suggest that more far-reaching conditions be met. The purpose of imposing conditions is to enhance the chances of success of the programs, and to increase thereby as much as possible the effectiveness of aid flows. In order to obtain support from the Fund, beneficiary countries should submit coherent programs in the fields of basic education, health, sanitation and water supply. Such programs should be embedded in a credible national human development policy, a "Poverty Reduction Strategy", along the lines promoted by the HIPC Initiative. Credibility of such a strategy crucially depends on the existence of good government practices, of suitable institutions and of sound macroeconomic policies.

Good governance should include transparency and accountability. Transparency refers to the budgetary process and to the activities as such. The former should be subject to clear cut rules, which ensure overall coherence of the budget and controls of its execution. Transparency of the activities can be promoted by regular and accurate reporting. The different levels of government should in the first place be accountable to their own constituencies. This requires some form of democratic practices. The beneficiary countries should not be accountable to the PAIR Fund for the details of their activities. It is more important that the PAIR Fund focuses, as part of its conditionality assessment, on the general quality of the national policy framework.

Institutions in the field of human development should be reasonably effective in pursuing their goals. The criteria for appreciating their effectiveness in poor countries cannot be the same as those applied in rich countries; poverty is also reflected in the institutional capabilities. Nevertheless it is clear that a minimum of effectiveness is necessary in order to implement human development programs. Like the national and local authorities, the operations of the institutions in the field of human development should satisfy requirements of transparency and accountability.

The sustainability of human development policies also depends on sound macroeconomic policies which make it possible to generate the necessary public funds and foreign exchange for economic and human development and for serving the remaining debt. Such macroeconomic policies should aim at reasonably low inflation, limited public deficits and a sustainable balance of payments. In case of disequilibria the countries themselves should elaborate adjustment policies which respect the needs of human development.

Conditionality will be defined by the board of the PAIR Fund and monitored by it. Given that all parties are represented on this board, it can be expected that conditionality will be designed in such a way that its enforcement will generally be well accepted. Also, the long term perspective of the proposal provides a framework in which the conditionality can be more efficiently monitored and where progressivity in the conditions to be fulfilled can more easily be introduced. This should moreover provide additional incentives for the countries to comply.

\section{Relation to the literature on debt reduction}

Issues raised by debt reduction have been widely discussed in the academic literature since the inception of the early eighties' debt crisis. We briefly show how the main features of our 
proposal address several of the critical issues put forward by this literature.

\subsection{Rationale and pitfalls of debt reduction}

At the onset of the debt crisis, debt rescheduling and continued "voluntary lending" was the only instrument of the International Debt Strategy, mostly designed to prevent a melt-down of the international financial system ${ }^{16}$. Gradually however, the expectation that highly indebted countries would "grow out of debt" and regain a spontaneous access to international financial markets was proven wrong. The necessity to allow for some reduction of debt stocks and debt service gained growing support. Sachs (1989) was one of the first to advocate this approach which centred around the concept of debt overhang, i.e. the disincentive for an over-indebted country to invest and adjust. Krugman (1988) crystallised this concept into a 'debt relief Laffer curve', according to which an optimal amount of debt reduction could improve both the debtor's and the creditor's welfare. Empirical estimations of this debt Laffer curve (e.g. Claessens, 1990, and Cohen, 1991) showed that this was more than a theoretical assumption. Several debt reduction schemes were implemented, mainly for highly-indebted medium income countries for which an active secondary market in their bank held debt existed.

The disincentive aspects of debt overhang clearly carry over to our set of poor countries, although two additional arguments should be considered. First, poor countries benefit from aid flows from rich countries; as most of these countries' debt is with respect to official creditors, aid flows may be closely linked to debt service. Debt reduction might therefore be less productive in restoring the incentives to invest and adjust (Claessens et al. 1997). To avoid this, a clear commitment, embodied in our proposal, that debt reduction will be additional to current aid efforts by rich countries is necessary. A second argument relates to the additional effect that debt reduction has on uncertainty. Evidence surveyed by Claessens et al. (1997, p. 250) shows that the positive effects of debt reduction under the "Brady deals" can primarily be attributed to the removal of "uncertainty associated with continual ongoing debt reschedulings" and in "bolstering the confidence in the process of policy reform". This is exactly what our proposal aims at achieving in the field of human development.

The pitfalls of debt reduction have been extensively discussed in Buiter et al. (1987, 1989). On the debtors' side one may end up with an adverse selection effect, rewarding the "profligate and punishing the prudent". Moral hazard may also be a problem. These pitfalls are of course magnified when full debt cancellation is considered. On the creditor's side, debt reduction can be sub-optimal because of a free-riding problem within and between creditor classes. This issue and, more generally, that of burden sharing among creditors cannot easily be solved outside a multilateral framework, an approach embraced by the PAIR fund.

\subsection{A multilateral approach to debt reduction}

Although several aspects of multilaterality were embodied in the International Debt Strategy (e.g. the IMF's backing and even arms-twisting in "Brady deals", the multilateral negotiations between creditors within the Paris and London Clubs, the G-7 implications in the HIPC

\footnotetext{
${ }^{46}$ For a survey of this IMF-sponsored strategy, see e.g. Smith and Cuddington(1985).

${ }^{47}$ Most middle-income countries highly indebted with commercial banks benefited from these IMF- and World Bank sponsored deals in which creditors exchanged new senior debt titles, enhanced by collaterals, against comprehensive debt stocks or debt service reductions. For an evaluation of these deals, see e.g. Van Wijnbergen (1990) for the case of Mexico.
} 
negotiations ...), the idea of an full-fledged "international debt facility" which would buy back the whole outstanding debt stock of the over-indebted countries - as first voiced by Kenen (1983) - never gained much support neither on the policy side of the debate nor within academic circles ${ }^{4}$. Bulow and Rogoff (1990) in particular criticised such an international debt facility on two grounds : first, the debt buy back on the open secondary market underlying the scheme could be expected to be too costly and therefore represent an inefficient allocation of funds available to the debtors; second, countries could be expected to be better off negotiating debt reductions directly with their creditors, without interference from an official intermediary. It is to be noted that both these criticisms are questionable in the case of debt with respect to official creditors, as is the case in the PAIR proposal : given the absence of a secondary market for this type of debt, a fair price can much more easily be determined as part of the multilateral negotiation between creditors; also, the outcome of bilateral negotiations between a debtor country and its official creditors often hinge on the political agenda of the different creditors, while this is much less so the case in a multilateral framework. A truly multilateral approach also has the advantage of achieving greater fairness in the burden sharing among creditors (Bulow et al, 1992 ; Berthélémy and Vourc'h, 1991), notably because it also includes the multilateral creditors. This is indeed the case for the HIPC initiative. In addition, the buy back of a country's total stock of debt by the PAIR fund makes the Fund the sole creditor and thereby nicely solves any potential problems linked to differences in seniority among creditors.

\subsection{Debt reduction and aid}

The link between debt reduction or cancellation and flows of aid to developing countries has only been made recently, particularly in the discussions leading up to the HIPC initiative (Claessens et al., 1997). Bulow and Rogoff (1990) however already pointed out that a debt buy-back financed by donors would represent a misallocation of aid funds whenever the buyback price exceeded the marginal benefit to the country. The PAIR fund minimises this risk, on the one hand by selecting a fair buy back value for the debt through a multilateral negotiation with the official creditors and on the other hand by requesting countries to allocate to human development projects part of the funds saved by debt and debt service reduction.

Co-ordination between debt reduction and aid in a multilateral framework, together with a clear priority for human development, has particularly been stressed by the enhanced HIPC initiative (for an appraisal see e.g. Foster et al, 1999). Sachs et al. (1999) plead for a similar human development approach, but with much deeper, near complete debt forgiveness. The Corda proposal (Drèze et al., 1991) can also be characterised as a first attempt to make explicit the link between aid, debt and development. Indeed it incorporates elements of the 'international debt facility' approach into a revolving fund structure to finance development for a group of countries, the ACP countries.

\footnotetext{
${ }^{48}$ see Corden (1988) for a comprehensive review of the schemes proposed and the advantages and problems with this approach. Sachs (1990) and Drèze et al. (1991) also elaborated debt reduction proposals based on such a multilateral approach. Note that the same scepticism was addressed to proposals to install an international bankruptcy court or code, along the lines of US domestic (Chapter 9) bankruptcy code (e.g. Raffer, 1990).

${ }^{49} \mathrm{On}$ an open-market, the debt has to be bought back at an average price, although it is the much lower marginal
} 
Table 1 : DEBT and Human Development Indicators on HIPC and Non-HIPC Poor Countries

(millions of U.S. dollars or otherwise indicated - sources : Global Development Finance 1999 ; Human Development Report 1999 ; World Developr Report 98-99 for ODA, infant mortality and enrolment indicators)

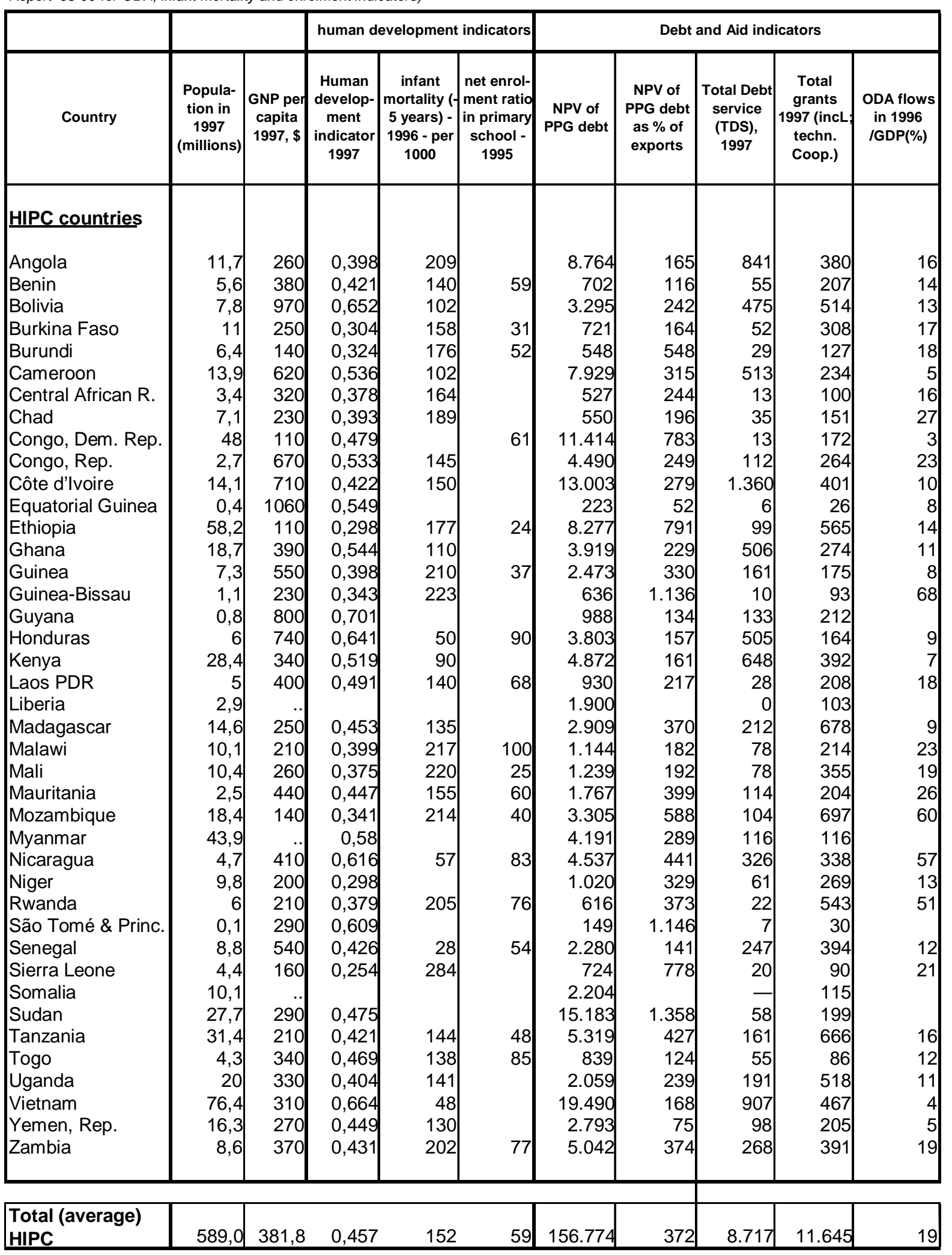

price which represents for the country the expected benefit of the buy-back. 
Table 1 (continued) : DEBT and Human Development Indicators on HIPC and Non-HIPC Poor Countries

\begin{tabular}{|c|c|c|c|c|c|c|c|c|c|c|}
\hline \multirow[b]{2}{*}{ Country } & \multirow[b]{2}{*}{$\begin{array}{c}\text { Popula- } \\
\text { tion in } \\
1997 \\
\text { (millions) }\end{array}$} & \multirow[b]{2}{*}{$\begin{array}{c}\text { GNP pe } \\
\text { capita } \\
1997, \$\end{array}$} & \multicolumn{3}{|c|}{ human development indicator } & \multicolumn{5}{|c|}{ Debt and Aid indicators } \\
\hline & & & $\begin{array}{c}\text { Human } \\
\text { develop- } \\
\text { ment } \\
\text { indicator } \\
1997\end{array}$ & $\begin{array}{c}\text { infant } \\
\text { mortality ( } \\
5 \text { years) - } \\
1996-\text { per } \\
1000\end{array}$ & $\begin{array}{c}\text { net enrol- } \\
\text { ment ratid } \\
\text { in primary } \\
\text { school - } \\
1995\end{array}$ & $\begin{array}{l}\text { NPV of } \\
\text { PPG debt }\end{array}$ & $\begin{array}{l}\text { NPV of } \\
\text { PPG debt } \\
\text { as \% of } \\
\text { exports }\end{array}$ & $\begin{array}{c}\text { Total Debt } \\
\text { service } \\
\text { (TDS), } \\
1997\end{array}$ & \begin{tabular}{|c|} 
Total \\
grants \\
1997 (incL \\
techn. \\
Coop.)
\end{tabular} & $\begin{array}{c}\text { ODA flows } \\
\text { in } 1996 \\
\text { /GDP(\%) }\end{array}$ \\
\hline \multicolumn{11}{|c|}{ NON-HIPC countries with HDI lower than 0.5 in 1997} \\
\hline Bangladesh & 122,7 & 360 & 0,44 & 112 & & 8.650 & 130 & 705 & 818 & 4 \\
\hline Bhutan & 1,9 & 430 & 0,459 & & & 47 & 39 & 6 & 60 & \\
\hline Djibouti & 0,6 & & 0,412 & & & 175 & 75 & 7 & 70 & \\
\hline Eritrea & 3,4 & 230 & 0,346 & & & 36 & 9 & 1 & 101 & \\
\hline Gambia, The & 1,2 & 340 & 0,391 & & & 227 & 97 & 27 & 33 & \\
\hline Haiti & 7,8 & 380 & 0,43 & 130 & & 595 & 273 & 35 & 249 & 14 \\
\hline Nepal & 22,3 & 220 & 0,463 & 116 & & 1.249 & 86 & 98 & 282 & 9 \\
\hline Nigeria & 103,9 & 280 & 0,456 & 130 & & 26.968 & 148 & 1.416 & 111 & 1 \\
\hline Non-HIPC Poor & 263,8 & 320 & 0,425 & 122 & & 37.947 & 107 & 2.295 & 1.724 & 7 \\
\hline \multicolumn{11}{|l|}{ Total (average) } \\
\hline HIPC + Non-HIPC & & & & & & & & & & \\
\hline Poor & 852,8 & 372,2 & 0,451 & 148 & & 194.721 & 327 & 11.012 & 13.369 & 18 \\
\hline
\end{tabular}


Table 2 : Face Value and NPV of Eligible Debt of HIPC and Non-HIPC Poor Countries millions of U.S. dollars - source : Government Development Finance 1999

\begin{tabular}{|c|c|c|c|c|c|c|c|c|c|c|c|c|c|}
\hline \multirow{4}{*}{ Country } & \multicolumn{8}{|c|}{ Eligible PPG Debt, at face value (1) } & & \multirow{4}{*}{$\begin{array}{l}\text { Non eligible } \\
\text { Short term } \\
\text { PPG debt } \\
\text { (2) }\end{array}$} & \multirow{4}{*}{$\begin{array}{c}\text { Total PPG } \\
\text { debt stocks } \\
(3)=(1)+(2)\end{array}$} & \multirow{4}{*}{$\begin{array}{l}\text { NPV of total } \\
\text { PPG debt } \\
\text { (4) }\end{array}$} & \multirow{4}{*}{$\begin{array}{c}\text { NPV of } \\
\text { Eligible PPG } \\
\text { debt } \quad(5)= \\
\text { (4)-(2) }\end{array}$} \\
\hline & \multicolumn{5}{|c|}{ Long term debt, public and publicly garanteed } & \multirow[b]{3}{*}{ total } & \multirow{3}{*}{$\begin{array}{l}\text { Interest } \\
\text { arrears on } \\
\text { long term } \\
\text { debt }\end{array}$} & \multirow{3}{*}{$\begin{array}{c}\text { IMF short } \\
\text { term Credit }\end{array}$} & & & & & \\
\hline & \multicolumn{2}{|c|}{ multilateral } & \multicolumn{2}{|c|}{ bilateral } & \multirow{2}{*}{$\begin{array}{c}\text { private } \\
\text { credi-tors }\end{array}$} & & & & & & & & \\
\hline & total & $\begin{array}{l}\text { conces- } \\
\text { sional }\end{array}$ & total & $\begin{array}{c}\text { conces- } \\
\text { sional }\end{array}$ & & & & & & & & & \\
\hline \multicolumn{14}{|l|}{ HIPC countries } \\
\hline Angola & 234 & 168 & 2.658 & 2.062 & 5.994 & 8.885 & 555 & 0 & 9.440 & 720 & 10.160 & 8.764 & 8.044 \\
\hline Benin & 871 & 852 & 519 & 413 & 3 & 1.393 & 8 & 95 & 1.496 & 128 & 1.624 & 702 & 574 \\
\hline Bolivia & 2.681 & 1.685 & 1.421 & 1.280 & 42 & 4.144 & 4 & 248 & 4.395 & 426 & 5.247 & 3.295 & 2.869 \\
\hline Burkina Faso & 1.003 & 953 & 132 & 124 & 4 & 1.139 & 7 & 92 & 1.238 & 59 & 1.297 & 721 & 662 \\
\hline Burundi & 872 & 840 & 149 & 149 & 1 & 1.022 & 9 & 28 & 1.058 & 7 & 1.066 & 548 & 541 \\
\hline Cameroon & 1.464 & 735 & 5.644 & 3.220 & 580 & 7.688 & 185 & 93 & 7.966 & 1.129 & 9.293 & 7.929 & 6.800 \\
\hline Central African R. & 607 & 593 & 183 & 134 & 14 & 804 & 45 & 19 & 867 & 18 & 885 & 527 & 509 \\
\hline Chad & 749 & 710 & 173 & 94 & 17 & 939 & 7 & 61 & 1.007 & 19 & 1.026 & 550 & 531 \\
\hline Congo, Dem. Rep & 2.179 & 1.536 & 5.604 & 1.566 & 834 & 8.617 & 2.941 & 407 & 11.965 & 365 & 12.330 & 11.414 & 11.049 \\
\hline Congo, Rep. & 619 & 239 & 2.832 & 1.615 & 832 & 4.284 & 372 & 34 & 4.689 & 382 & 5.071 & 4.490 & 4.108 \\
\hline Côte d'Ivoire & 3.301 & 1.431 & 4.605 & 3.076 & 2.521 & 10.427 & 87 & 450 & 10.964 & 2.574 & 15.609 & 13.003 & 10.429 \\
\hline Equatorial Guinea & 94 & 84 & 101 & 55 & 14 & 209 & 37 & 13 & 259 & 24 & 283 & 223 & 199 \\
\hline Ethiopia & 2.459 & 2.233 & 6.613 & 6.400 & 354 & 9.426 & 541 & 87 & 10.054 & 24 & 10.078 & 8.277 & 8.253 \\
\hline Ghana & 3.179 & 2.960 & 1.075 & 1.015 & 437 & 4.691 & 13 & 347 & 5.051 & 664 & 5.982 & 3.919 & 3.255 \\
\hline Guinea & 1.557 & 1.301 & 1.380 & 1.183 & 72 & 3.008 & 100 & 99 & 3.207 & 313 & 3.520 & 2.473 & 2.160 \\
\hline Guinea-Bissau & 387 & 372 & 451 & 294 & 1 & 838 & 63 & 12 & 913 & 8 & 921 & 636 & 628 \\
\hline Guyana & 666 & 574 & 623 & 335 & 56 & 1.345 & 93 & 157 & 1.595 & 16 & 1.611 & 988 & 972 \\
\hline Honduras & 2.303 & 1.307 & 1.368 & 980 & 240 & 3.910 & 57 & 46 & 4.013 & 425 & 4.698 & 3.803 & 3.378 \\
\hline Kenya & 2.785 & 2.382 & 1.860 & 1.345 & 463 & 5.108 & 34 & 250 & 5.392 & 769 & 6.486 & 4.872 & 4.103 \\
\hline Laos PDR & 816 & 816 & 1.431 & 1.427 & 0 & 2.247 & 0 & 66 & 2.313 & 7 & 2.320 & 930 & 923 \\
\hline Liberia & 405 & 197 & 465 & 388 & 192 & 1.061 & 612 & 305 & 1.978 & 34 & 2.012 & 1.900 & 1.866 \\
\hline Madagascar & 1.661 & 1.560 & 2.166 & 1.119 & 45 & 3.871 & 153 & 69 & 4.094 & 11 & 4.105 & 2.909 & 2.898 \\
\hline Malawi & 1.791 & 1.702 & 261 & 245 & 21 & 2.073 & 7 & 106 & 2.186 & 20 & 2.206 & 1.144 & 1.124 \\
\hline Mali & 1.453 & 1.424 & 1.234 & 1.197 & 0 & 2.687 & 43 & 176 & 2.905 & 40 & 2.945 & 1239 & 1.199 \\
\hline Mauritania & 938 & 774 & 1.075 & 924 & 24 & 2.037 & 86 & 113 & 2.235 & 218 & 2.453 & 1.767 & 1.549 \\
\hline Mozambique & 1.626 & 1.533 & 3.786 & 1.852 & 18 & 5.430 & 209 & 189 & 5.827 & 118 & 5.991 & 3305 & 3.187 \\
\hline Myanmar & 1.171 & 1.170 & 3.017 & 2.920 & 452 & 4.640 & 390 & 0 & 5.030 & 44 & 5.074 & 4.191 & 4.147 \\
\hline Nicaragua & 1.571 & 1.307 & 2.854 & 1.202 & 394 & 4.819 & 567 & 27 & 5.413 & 265 & 5.677 & 4.537 & 4.272 \\
\hline
\end{tabular}


Table 2 (continued) : Face value and NPV of Eligible Debt of HIPC and Non-HIPC Countries

\begin{tabular}{|c|c|c|c|c|c|c|c|c|c|c|c|c|c|}
\hline \multirow{4}{*}{ Country } & \multicolumn{6}{|c|}{ Eligible PPG Debt, at face value } & \multicolumn{2}{|l|}{ (1) } & & \multirow{4}{*}{$\begin{array}{l}\text { Non eligible } \\
\text { Short term } \\
\text { PPG debt } \\
\text { (2) }\end{array}$} & \multirow{4}{*}{$\begin{array}{c}\text { Total PPG } \\
\text { debt stocks } \\
(3)=(1)+(2)\end{array}$} & \multirow{4}{*}{$\begin{array}{l}\text { NPV of total } \\
\text { PPG debt } \\
\text { (4) }\end{array}$} & \multirow{4}{*}{$\begin{array}{c}\text { NPV of } \\
\text { Eligible PPG } \\
\text { debt (5) }= \\
\text { (4)-(2) }\end{array}$} \\
\hline & \multicolumn{6}{|c|}{ Long term debt, public and publicly garanteed } & \multirow{3}{*}{$\begin{array}{c}\text { Interest } \\
\text { arrears on } \\
\text { long term } \\
\text { debt }\end{array}$} & \multirow{3}{*}{$\begin{array}{c}\text { IMF short } \\
\text { term Credit }\end{array}$} & & & & & \\
\hline & \multicolumn{2}{|c|}{ multilateral } & \multicolumn{2}{|c|}{ bilateral } & \multirow{2}{*}{$\begin{array}{c}\text { private } \\
\text { credi-tors }\end{array}$} & \multirow[b]{2}{*}{ total } & & & & & & & \\
\hline & total & \begin{tabular}{c|}
$\begin{array}{c}\text { conces- } \\
\text { sional }\end{array}$ \\
\end{tabular} & total & $\begin{array}{c}\begin{array}{c}\text { conces- } \\
\text { sional }\end{array} \\
\end{array}$ & & & & & & & & & \\
\hline Niger & 881 & 843 & 450 & 214 & 0 & 1.331 & 35 & 61 & 1.426 & 57 & 1.579 & 1.020 & 963 \\
\hline Rwanda & 850 & 850 & 142 & 136 & 1 & 994 & 29 & 40 & 1.063 & 48 & 1.111 & 616 & 568 \\
\hline São Tomé \& Pr. & 156 & 155 & 71 & 68 & 0 & 227 & 5 & 0 & 232 & 29 & 261 & 149 & 120 \\
\hline Senegal & 1.803 & 1.604 & 1.297 & 791 & 10 & 3.110 & 2 & 292 & 3.404 & 211 & 3.671 & 2280 & 2.069 \\
\hline Sierra Leone & 494 & 475 & 393 & 258 & 6 & 893 & 3 & 167 & 1.063 & 86 & 1.149 & 724 & 638 \\
\hline Somalia & 723 & 706 & 1.095 & 797 & 34 & 1.852 & 534 & 151 & 2.537 & 24 & 2.561 & 2204 & 2.180 \\
\hline Sudan & 2.001 & 1.798 & 5.521 & 2.838 & 1.477 & 8.998 & 5.624 & 797 & 15.419 & 411 & 16.326 & 15183 & 14.772 \\
\hline Tanzania & 2.939 & 2.813 & 2.866 & 2.278 & 248 & 6.054 & 698 & 246 & 6.997 & 139 & 7.177 & 5.319 & 5.180 \\
\hline Togo & 717 & 703 & 491 & 252 & 0 & 1.207 & 3 & 88 & 1.298 & 41 & 1.339 & 839 & 798 \\
\hline Uganda & 2.399 & 2.331 & 727 & 619 & 76 & 3.202 & 44 & 394 & 3.640 & 68 & 3.708 & 2.059 & 1.991 \\
\hline Vietnam & 828 & 819 & 13.274 & 2.390 & 4.737 & 18.839 & 1.387 & 452 & 20.678 & 951 & 21.629 & 19.490 & 18.539 \\
\hline Yemen, Rep. & 1.390 & 1.331 & 1.191 & 1.080 & 837 & 3.418 & 68 & 250 & 3.736 & 120 & 3.856 & 2.793 & 2.673 \\
\hline Zambia & 2.227 & 1.989 & 2.864 & 1.808 & 143 & 5.233 & 253 & 1.138 & 6.624 & 121 & 6.758 & 5.042 & 4.921 \\
\hline
\end{tabular}

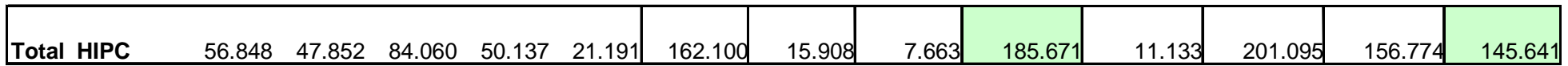

NON-HIPC countries with HDI lower than 0.5 in 1997

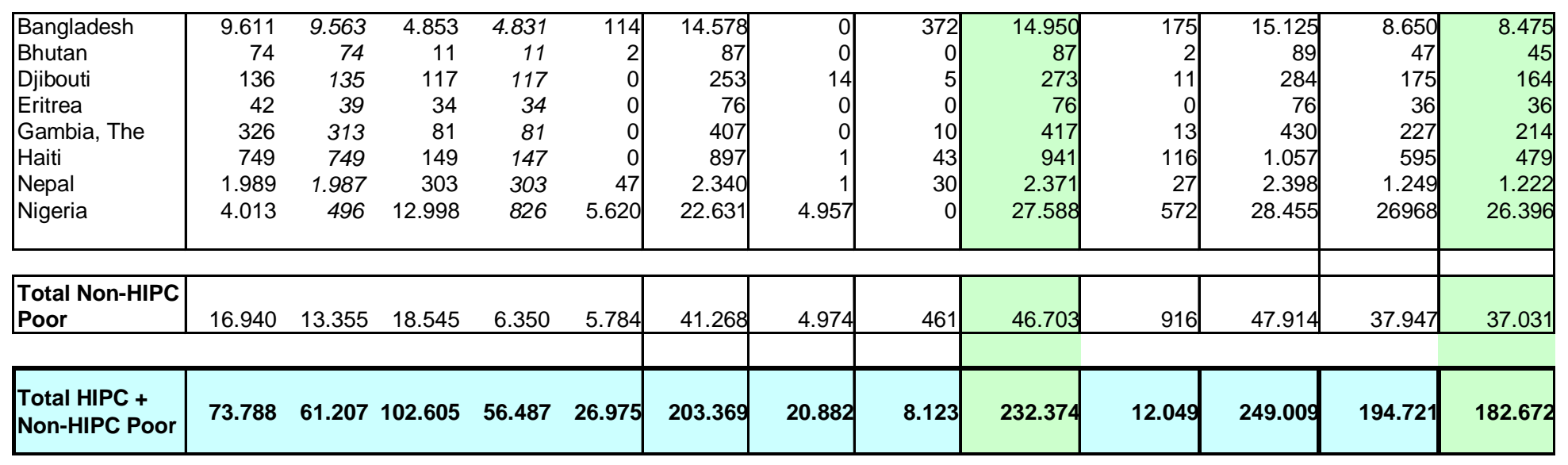


Table 3 : Estimate of cost of debt cancelation for HIPC and Non-HIPC Poor Countries

millions of U.S. dollars, 1997 data - source : table 2 ; see text for discussion

\begin{tabular}{|c|c|c|c|c|c|c|c|c|c|c|c|c|}
\hline \multirow{4}{*}{ Country } & \multirow{4}{*}{$\begin{array}{c}\text { Eligible Debt } \\
\text { at face value } \\
\text { (1) }\end{array}$} & \multirow{4}{*}{\begin{tabular}{|c|} 
NPV of \\
eligible debt \\
(2)
\end{tabular}} & \multirow{4}{*}{$\begin{array}{c}\text { Face value of } \\
\text { non } \\
\text { concessional } \\
\text { eligible debt } \\
\text { (3) }\end{array}$} & \multirow{4}{*}{\begin{tabular}{|c|} 
Face value \\
of concessio \\
nal PPG \\
debt \\
(4)
\end{tabular}} & \multirow{4}{*}{$\begin{array}{c}\text { Estimate of } \\
\text { ratio } \\
\text { (NPV/face } \\
\text { value) for } \\
\text { concessio- } \\
\text { nal debt } \\
(5)=[(2)- \\
(3)] /(4)\end{array}$} & \multicolumn{5}{|c|}{$\begin{array}{c}\text { Estimate of budgetary cost of cancellation of total debt held by } \\
\text { official creditors }\end{array}$} & \multirow{3}{*}{\begin{tabular}{|c} 
Estimate of \\
residual \\
"buy back" \\
value of LT \\
debt to \\
private \\
creditors if \\
"pari passu" \\
effort \\
reduces \\
value to
\end{tabular}} & \multirow{3}{*}{$\begin{array}{c}\text { Implied } \\
\text { amounts of } \\
\text { balance- } \\
\text { sheet write- } \\
\text { off (wrt face } \\
\text { value) for } \\
\text { official } \\
\text { creditors on } \\
\text { total } \\
\text { bilateral } \\
\text { debt (12) }\end{array}$} \\
\hline & & & & & & \multirow{3}{*}{$\begin{array}{l}100 \% \text { of } \\
\text { multilateral } \\
\text { non } \\
\text { concessio- } \\
\text { nal debt } \\
(6)\end{array}$} & \multirow{3}{*}{$\begin{array}{c}100 \% \text { of } \\
\text { estimated } \\
\text { NPV of } \\
\text { multilateral } \\
\text { concessional } \\
\text { debt }(7)= \\
(5)^{\star} \text { Face } \\
\text { value }^{\star \star \star}\end{array}$} & $30 \%$ & $15 \%$ & \multirow{3}{*}{$\begin{array}{l}\text { total cost } \\
(10)\end{array}$} & & \\
\hline & & & & & & & & \multirow[t]{2}{*}{$\begin{array}{c}\text { of bilateral } \\
\text { non } \\
\text { concessio- } \\
\text { nal debt } \\
\text { (incl. interest } \\
\text { arrears) } \\
\text { (8) }\end{array}$} & \multirow[t]{2}{*}{$\begin{array}{c}\text { of estimated } \\
\text { NPV of } \\
\text { bilateral } \\
\text { concessio- } \\
\text { nal debt }(9)= \\
(5){ }^{\star} \text { Face } \\
\text { value }^{\star * \star}\end{array}$} & & & \\
\hline & & & & & & & & & & & $30 \%$ & \\
\hline \multicolumn{13}{|l|}{ HIPC countries } \\
\hline Angola & 9.440 & 8.044 & 7.210 & 2.230 & 0,374 & 65 & 63 & 345 & 116 & 589 & 1.798 & 2.752 \\
\hline Benin & 1.496 & 574 & 231 & 1.265 & 0,271 & 114 & 231 & 34 & 17 & 396 & 1 & 476 \\
\hline Bolivia & 4.395 & 2.869 & 1.431 & 2.964 & 0,485 & 1.245 & 817 & 43 & 93 & 2.198 & 13 & 1.288 \\
\hline Burkina Faso & 1.238 & 662 & 161 & 1.077 & 0,465 & 142 & 443 & 4 & 9 & 599 & 1 & 126 \\
\hline Burundi & 1.058 & 541 & 69 & 989 & 0,477 & 60 & 400 & 3 & 11 & 474 & 0 & 145 \\
\hline Cameroon & 7.966 & 6.800 & 4.012 & 3.954 & 0,705 & 823 & 518 & 783 & 341 & 2.464 & 174 & 4.706 \\
\hline Central African Repul & 867 & 509 & 141 & 726 & 0,507 & 33 & 300 & 28 & 10 & 371 & 4 & 190 \\
\hline Chad & 1.007 & 531 & 203 & 804 & 0,408 & 100 & 289 & 26 & 6 & 421 & 5 & 149 \\
\hline Congo, Dem. Rep. & 11.965 & 11.049 & 8.863 & 3.102 & 0,705 & 1.049 & 1.083 & 2.094 & 166 & 4.391 & 250 & 6.286 \\
\hline Congo, Rep. & 4.689 & 4.108 & 2.835 & 1.854 & 0,687 & 414 & 164 & 477 & 166 & 1.221 & 250 & 2.561 \\
\hline Côte d'Ivoire & 10.964 & 10.429 & 6.457 & 4.507 & 0,881 & 2.320 & 1.261 & 485 & 407 & 4.473 & 756 & 3.800 \\
\hline Equatorial Guinea & 259 & 199 & 121 & 138 & 0,564 & 23 & 47 & 25 & 5 & 100 & 4 & 108 \\
\hline Ethiopia & 10.054 & 8.253 & 1.422 & 8.633 & 0,791 & 313 & 1.767 & 226 & 760 & 3.066 & 106 & 6.168 \\
\hline Ghana & 5.051 & 3.255 & 1.076 & 3.975 & 0,548 & 566 & 1.623 & 22 & 83 & 2.294 & 131 & 983 \\
\hline Guinea & 3.207 & 2.160 & 723 & 2.484 & 0,578 & 355 & 752 & 89 & 103 & 1.299 & 22 & 1.288 \\
\hline Guinea-Bissau & 913 & 628 & 248 & 666 & 0,571 & 27 & 212 & 66 & 25 & 331 & 0 & 422 \\
\hline Guyana & 1.595 & 972 & 685 & 909 & 0,315 & 248 & 181 & 114 & 16 & 560 & 17 & 586 \\
\hline Honduras & 4.013 & 3.378 & 1.726 & 2.287 & 0,722 & 1.041 & 944 & 134 & 106 & 2.225 & 72 & 1.185 \\
\hline Kenya & 5.392 & 4.103 & 1.665 & 3.727 & 0,654 & 653 & 1.558 & 165 & 132 & 2.508 & 139 & 1.597 \\
\hline
\end{tabular}

${ }^{* * *}$ Face value of applicable creditor class (see table 2) 
Table 3 (continued) Estimate of cost of debt cancellation for HIPC and Non-HIPC Poor Countries

\begin{tabular}{|c|c|c|c|c|c|c|c|c|c|c|c|c|}
\hline \multirow{4}{*}{ Country } & \multirow{4}{*}{$\begin{array}{c}\text { Eligible Debt } \\
\text { at face value } \\
\text { (1) }\end{array}$} & \multirow{4}{*}{$\begin{array}{c}\mathrm{NPV} \text { of } \\
\text { eligible debt } \\
\text { (2) }\end{array}$} & \multirow{4}{*}{$\begin{array}{c}\text { Face value of } \\
\text { non } \\
\text { concessional } \\
\text { eligible debt } \\
\text { (3) }\end{array}$} & \multirow{4}{*}{\begin{tabular}{|} 
Face value \\
of concessio \\
nal PPG \\
debt \\
(4)
\end{tabular}} & \multirow{4}{*}{$\begin{array}{c}\text { Estimate of } \\
\text { ratio } \\
\text { (NPV/face } \\
\text { value) for } \\
\text { concessio- } \\
\text { nal debt } \\
(5)=[(2)- \\
(3)] /(4)\end{array}$} & \multicolumn{5}{|c|}{$\begin{array}{l}\text { Estimate of budgetary cost of cancellation of total debt held by } \\
\text { official creditors }\end{array}$} & \multirow{3}{*}{\begin{tabular}{|c|} 
Estimate of \\
residual \\
"buy back" \\
value of LT \\
debt to \\
private \\
creditors if \\
"pari passu" \\
effort \\
reduces \\
value to
\end{tabular}} & \multirow{3}{*}{$\begin{array}{c}\text { Implied } \\
\text { amounts of } \\
\text { balance- } \\
\text { sheet write- } \\
\text { off (wrt face } \\
\text { value) for } \\
\text { official } \\
\text { creditors on } \\
\text { total } \\
\text { bilateral } \\
\text { debt }\end{array}$} \\
\hline & & & & & & \multirow{3}{*}{$\begin{array}{l}100 \% \text { of } \\
\text { multilateral } \\
\text { non } \\
\text { concessio- } \\
\text { nal debt } \\
(6)\end{array}$} & \multirow{3}{*}{\begin{tabular}{|c|}
$100 \%$ of \\
estimated \\
NPV of \\
multilateral \\
concessional \\
debt $(7)=$ \\
$(5)^{\star}$ Face \\
value $^{\star \star *}$
\end{tabular}} & $30 \%$ & $15 \%$ & \multirow{3}{*}{$\begin{array}{l}\text { total cost } \\
\quad(10)\end{array}$} & & \\
\hline & & & & & & & & \multirow[t]{2}{*}{$\begin{array}{l}\text { of bilateral } \\
\text { non } \\
\text { concessio- } \\
\text { nal debt } \\
\text { (incl. interest } \\
\text { arrears) } \\
\text { (8) }\end{array}$} & \multirow[t]{2}{*}{$\begin{array}{c}\text { of estimated } \\
\text { NPV of } \\
\text { bilateral } \\
\text { concessio- } \\
\text { nal debt (9) }= \\
(5)^{\star} \text { Face } \\
\text { value }{ }^{\star \star \star}\end{array}$} & & & \\
\hline & & & & & & & & & & & $30 \%$ & \\
\hline Laos PDR & 2.313 & 923 & 69 & 2.243 & 0,380 & 66 & 310 & 1 & 81 & 459 & 0 & 1.348 \\
\hline Liberia & 1.978 & 1.866 & 1.393 & 585 & 0,809 & 513 & 159 & 207 & 47 & 925 & 58 & 823 \\
\hline Madagascar & 4.094 & 2.898 & 1.415 & 2.679 & 0,554 & 170 & 864 & 360 & 93 & 1.487 & 13 & 1.866 \\
\hline Malawi & 2.186 & 1.124 & 239 & 1.946 & 0,454 & 196 & 773 & 7 & 17 & 992 & 6 & 244 \\
\hline Mali & 2.905 & 1.199 & 284 & 2.621 & 0,349 & 205 & 497 & 24 & 63 & 788 & 0 & 1.190 \\
\hline Mauritania & 2.235 & 1.549 & 538 & 1.698 & 0,596 & 277 & 461 & 71 & 83 & 891 & 7 & 1.007 \\
\hline Mozambique & 5.827 & 3.187 & 2.442 & 3.385 & 0,220 & 281 & 337 & 643 & 61 & 1.323 & 5 & 3.290 \\
\hline Myanmar & 5.030 & 4.147 & 940 & 4.090 & 0,784 & 1 & 917 & 146 & 343 & 1.408 & 136 & 2.918 \\
\hline Nicaragua & 5.413 & 4.272 & 2.904 & 2.508 & 0,545 & 291 & 713 & 666 & 98 & 1.768 & 118 & 2.657 \\
\hline Niger & 1.426 & 963 & 369 & 1.057 & 0,562 & 98 & 474 & 81 & 18 & 671 & 0 & 386 \\
\hline Rwanda & 1.063 & 568 & 78 & 985 & 0,498 & 41 & 423 & 11 & 10 & 484 & 0 & 151 \\
\hline São Tomé and Princih & 232 & 120 & 9 & 223 & 0,499 & 2 & 77 & 2 & 5 & 86 & 0 & 68 \\
\hline Senegal & 3.404 & 2.069 & 1.010 & 2.394 & 0,442 & 491 & 709 & 152 & 52 & 1.406 & 3 & 1.094 \\
\hline Sierra Leone & 1.063 & 638 & 330 & 733 & 0,421 & 186 & 200 & 41 & 16 & 443 & 2 & 338 \\
\hline Somalia & 2.537 & 2.180 & 1.034 & 1.503 & 0,762 & 168 & 538 & 250 & 91 & 1.047 & 10 & 1.288 \\
\hline Sudan & 15.419 & 14.772 & 10.784 & 4.636 & 0,860 & 1.000 & 1.547 & 2.492 & 366 & 5.405 & 443 & 8.287 \\
\hline Tanzania & 6.997 & 5.180 & 1.906 & 5.091 & 0,643 & 372 & 1.809 & 386 & 220 & 2.787 & 74 & 2.959 \\
\hline Togo & 1.298 & 798 & 343 & 955 & 0,476 & 101 & 335 & 73 & 18 & 527 & 0 & 403 \\
\hline Uganda & 3.640 & 1.991 & 691 & 2.949 & 0,441 & 462 & 1.027 & 46 & 41 & 1.577 & 23 & 684 \\
\hline Vietnam & 20.678 & 18.539 & 17.470 & 3.209 & 0,333 & 461 & 273 & 3.682 & 119 & 4.535 & 1.421 & 10.860 \\
\hline Yemen, Rep. & 3.736 & 2.673 & 1.325 & 2.411 & 0,559 & 309 & 744 & 54 & 91 & 1.197 & 251 & 1.115 \\
\hline Zambia & 6.624 & 4.921 & 2.828 & 3.797 & 0,551 & 1.376 & 1.097 & 393 & 150 & 3.015 & 43 & 2.575 \\
\hline Total HIPC & 185.672 & 145.641 & 87.681 & 97.989 & & 16.659 & 26.940 & 14.950 & 4.653 & 63.201 & 6.358 & 80.366 \\
\hline
\end{tabular}

${ }^{\star * \star}$ Face value of applicable creditor class (see table 2 ) 
Table 3 (continued) : Estimate of cost of debt cancellation for HIPC and Non-HIPC Poor Countries

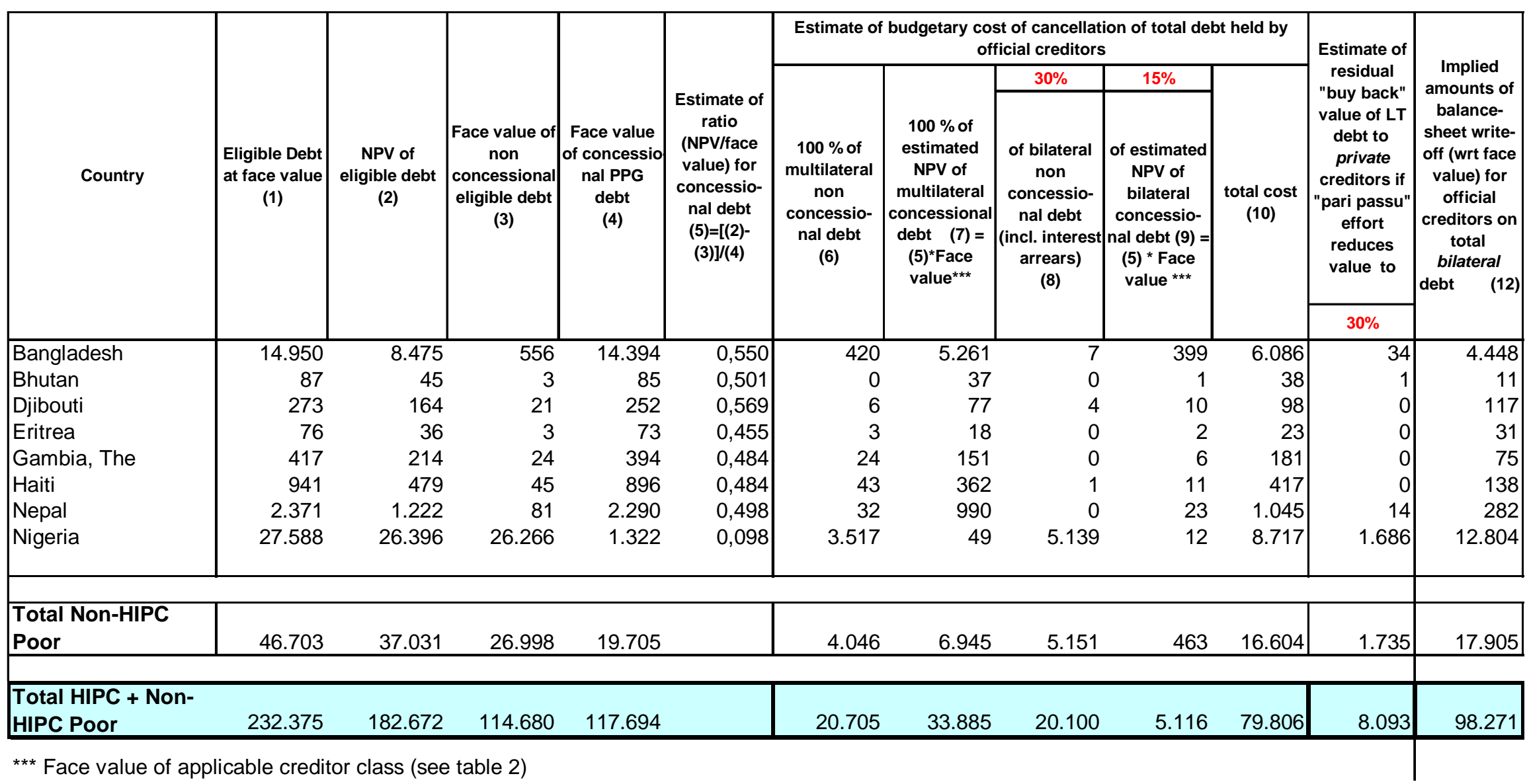


Table 4 : Upfront Cancellation of Eligible Debt to achieve NPV of Total Debt of maximum $30 \%$ of GNP

1997 data ; \$ millions except \$ billions for GNP ; sources : for NPV values see table 2, for GNP (current \$, World Bank Atlas data, World Development Report 98-99

\begin{tabular}{|c|c|c|c|c|c|c|c|}
\hline Country & GNP & $\begin{array}{l}\text { NPV of total } \\
\text { PPG debt }\end{array}$ & $\begin{array}{c}\text { NPV of } \\
\text { Eligible PPG } \\
\text { debt }\end{array}$ & $\begin{array}{l}\text { NPV of total } \\
\text { PPG debt as } \\
\% \text { of GNP }\end{array}$ & $\begin{array}{c}\text { Target } \\
\text { Ceiling for } \\
\text { NPV of total } \\
\text { PPG debt (= } \\
30 \% \text { of GNP) }\end{array}$ & $\begin{array}{c}\text { NPV of Eligilbel } \\
\text { debt to be } \\
\text { cancelled } \\
\text { upfront }\end{array}$ & $\begin{array}{l}\text { NPV of eligible } \\
\text { debt remaining } \\
\text { to be serviced }\end{array}$ \\
\hline \multicolumn{8}{|l|}{ HIPC countries } \\
\hline Angola & 3,0 & 8.764 & 8.044 & $291 \%$ & 904 & 7.860 & 184 \\
\hline Benin & 2,2 & 702 & 574 & $32 \%$ & 668 & 34 & 540 \\
\hline Bolivia & 7,6 & 3.295 & 2.869 & $44 \%$ & 2.269 & 1.026 & 1.843 \\
\hline Burkina Faso & 2,6 & 721 & 662 & $28 \%$ & 774 & 0 & 662 \\
\hline Burundi & 0,9 & 548 & 541 & $59 \%$ & 277 & 271 & 270 \\
\hline Cameroon & 8,6 & 7.929 & 6.800 & $92 \%$ & 2.583 & 5.346 & 1.454 \\
\hline Central African $\mathrm{A}$ & 1,1 & 527 & 509 & $48 \%$ & 331 & 196 & 313 \\
\hline Chad & 1,6 & 550 & 531 & $34 \%$ & 489 & 61 & 470 \\
\hline Congo, Dem. Re & 5,2 & 11.414 & 11.049 & $219 \%$ & 1.560 & 9.854 & 1.195 \\
\hline Congo, Rep. & 1,8 & 4.490 & 4.108 & $246 \%$ & 548 & 3.942 & 166 \\
\hline Côte d'Ivoire & 10,2 & 13.003 & 10.429 & $128 \%$ & 3.046 & 9.957 & 472 \\
\hline Equatorial Guine & 0,4 & 223 & 199 & $50 \%$ & 133 & 90 & 109 \\
\hline Ethiopia & 6,5 & 8.277 & 8.253 & $127 \%$ & 1.952 & 6.325 & 1.928 \\
\hline Ghana & 7,0 & 3.919 & 3.255 & $56 \%$ & 2.095 & 1.824 & 1.431 \\
\hline Guinea & 3,8 & 2.473 & 2.160 & $65 \%$ & 1.149 & 1.324 & 836 \\
\hline Guinea-Bissau & 0,3 & 636 & 628 & $241 \%$ & 79 & 557 & 71 \\
\hline Guyana & 0,7 & 988 & 972 & $146 \%$ & 203 & 785 & 187 \\
\hline Honduras & 4,4 & 3.803 & 3.378 & $86 \%$ & 1.328 & 2.475 & 903 \\
\hline Kenya & 9,7 & 4.872 & 4.103 & $50 \%$ & 2.896 & 1.976 & 2.127 \\
\hline Laos PDR & 1,9 & 930 & 923 & $48 \%$ & 577 & 353 & 570 \\
\hline Liberia & 0,9 & 1.900 & 1.866 & $218 \%$ & 261 & 1.639 & 227 \\
\hline Madagascar & 3,6 & 2.909 & 2.898 & $81 \%$ & 1.073 & 1.836 & 1.062 \\
\hline Malawi & 2,1 & 1.144 & 1.124 & $54 \%$ & 639 & 505 & 619 \\
\hline Mali & 2,7 & 1.239 & 1.199 & $47 \%$ & 797 & 442 & 757 \\
\hline Mauritania & 1,1 & 1.767 & 1.549 & $162 \%$ & 328 & 1.439 & 110 \\
\hline Mozambique & 2,4 & 3.305 & 3.187 & $137 \%$ & 721 & 2.584 & 603 \\
\hline Myanmar & 13,2 & 4.191 & 4.147 & $32 \%$ & 3.960 & 231 & 3.916 \\
\hline Nicaragua & 1,9 & 4.537 & 4.272 & $238 \%$ & 572 & 3.965 & 307 \\
\hline Niger & 2,0 & 1.020 & 963 & $52 \%$ & 589 & 431 & 532 \\
\hline Rwanda & 1,7 & 616 & 568 & $37 \%$ & 504 & 112 & 456 \\
\hline São Tomé and P & 0,0 & 149 & 120 & $368 \%$ & 12 & 137 & 0 \\
\hline Senegal & 4,8 & 2.280 & 2.069 & $48 \%$ & 1.433 & 847 & 1.222 \\
\hline Sierra Leone & 0,8 & 724 & 638 & $95 \%$ & 228 & 496 & 142 \\
\hline Somalia & 3,0 & 2.204 & 2.180 & $73 \%$ & 900 & 1.304 & 876 \\
\hline Sudan & 7,9 & 15.183 & 14.772 & $192 \%$ & 2.375 & 12.808 & 1.964 \\
\hline Tanzania & 6,6 & 5.319 & 5.180 & $80 \%$ & 1.990 & 3.329 & 1.851 \\
\hline Togo & 1,5 & 839 & 798 & $56 \%$ & 446 & 393 & 405 \\
\hline Uganda & 6,6 & 2.059 & 1.991 & $31 \%$ & 1.983 & 76 & 1.915 \\
\hline Vietnam & 24,0 & 19.490 & 18.539 & $81 \%$ & 7.202 & 12.288 & 6.251 \\
\hline Yemen, Rep. & 4,4 & 2.793 & 2.673 & $63 \%$ & 1.321 & 1.472 & 1.201 \\
\hline Zambia & 3,5 & 5.042 & 4.921 & $143 \%$ & 1.061 & 3.981 & 940 \\
\hline $\begin{array}{l}\text { Total (average) } \\
\text { HIPC }\end{array}$ & & 156.774 & 145.641 & $107 \%$ & & 104.571 & 41.087 \\
\hline
\end{tabular}


Table 4 (continued) Upfront Cancellation of Eligible Debt to achieve NPV of Total Debt of maximum 30\% of GNP

\begin{tabular}{|c|c|c|c|c|c|c|c|}
\hline Country & GNP & $\begin{array}{c}\text { NPV of total } \\
\text { PPG debt }\end{array}$ & $\begin{array}{c}\text { NPV of } \\
\text { Eligible PPG } \\
\text { debt }\end{array}$ & $\begin{array}{c}\text { NPV of total } \\
\text { PPG debt as } \\
\% \text { of GNP }\end{array}$ & $\begin{array}{c}\text { Target } \\
\text { Ceiling for } \\
\text { NPV of total } \\
\text { PPG debt (= } \\
30 \% \text { of GNP) }\end{array}$ & $\begin{array}{c}\text { NPV of Eligilbel } \\
\text { debt to be } \\
\text { cancelled } \\
\text { upfront }\end{array}$ & $\begin{array}{c}\text { NPV of eligible } \\
\text { debt remaining } \\
\text { to be serviced }\end{array}$ \\
\hline
\end{tabular}

\section{NON-HIPC countries with HDI lower than 0.5 in 1997}

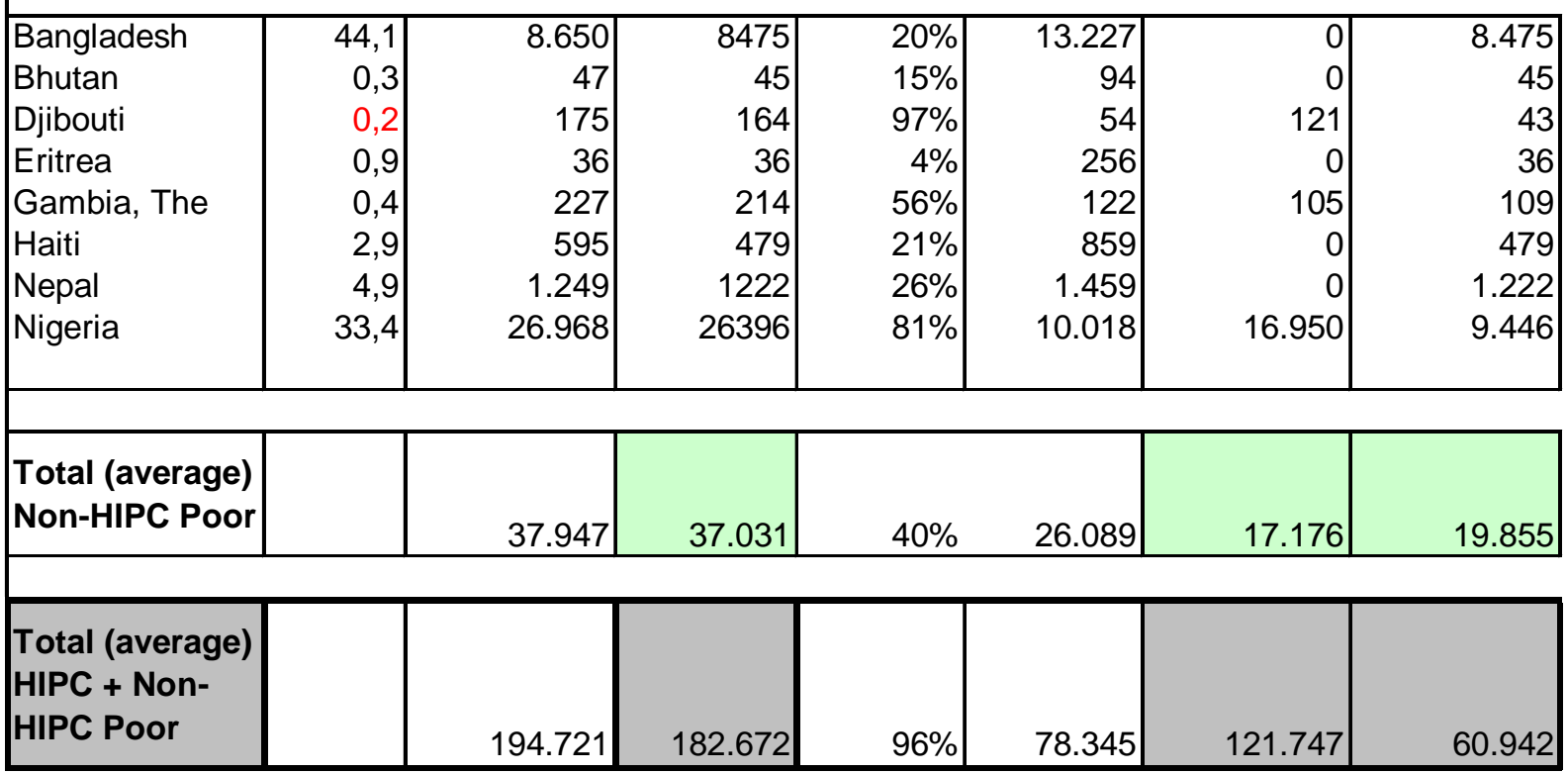

Note : for Liberia, Myanmar, Somalia and Djibouti, for which no GDP data exist, we postulate a GDP per capita equal to $\$ 300$ 


\begin{tabular}{|c|c|c|}
\hline \multicolumn{3}{|c|}{$\begin{array}{l}\text { Effort over } 15 \text { years } \quad 324,9 \text { billion } \$ \\
\text { combining two sharing rules, each rising half or the sum }\end{array}$} \\
\hline & * gamma in partial adjustment rule is set equal & 0.01425 \\
\hline & * additionalflat increase in ODA/GDP $\%$ is set equal to & $0.050 \%$ \\
\hline
\end{tabular}

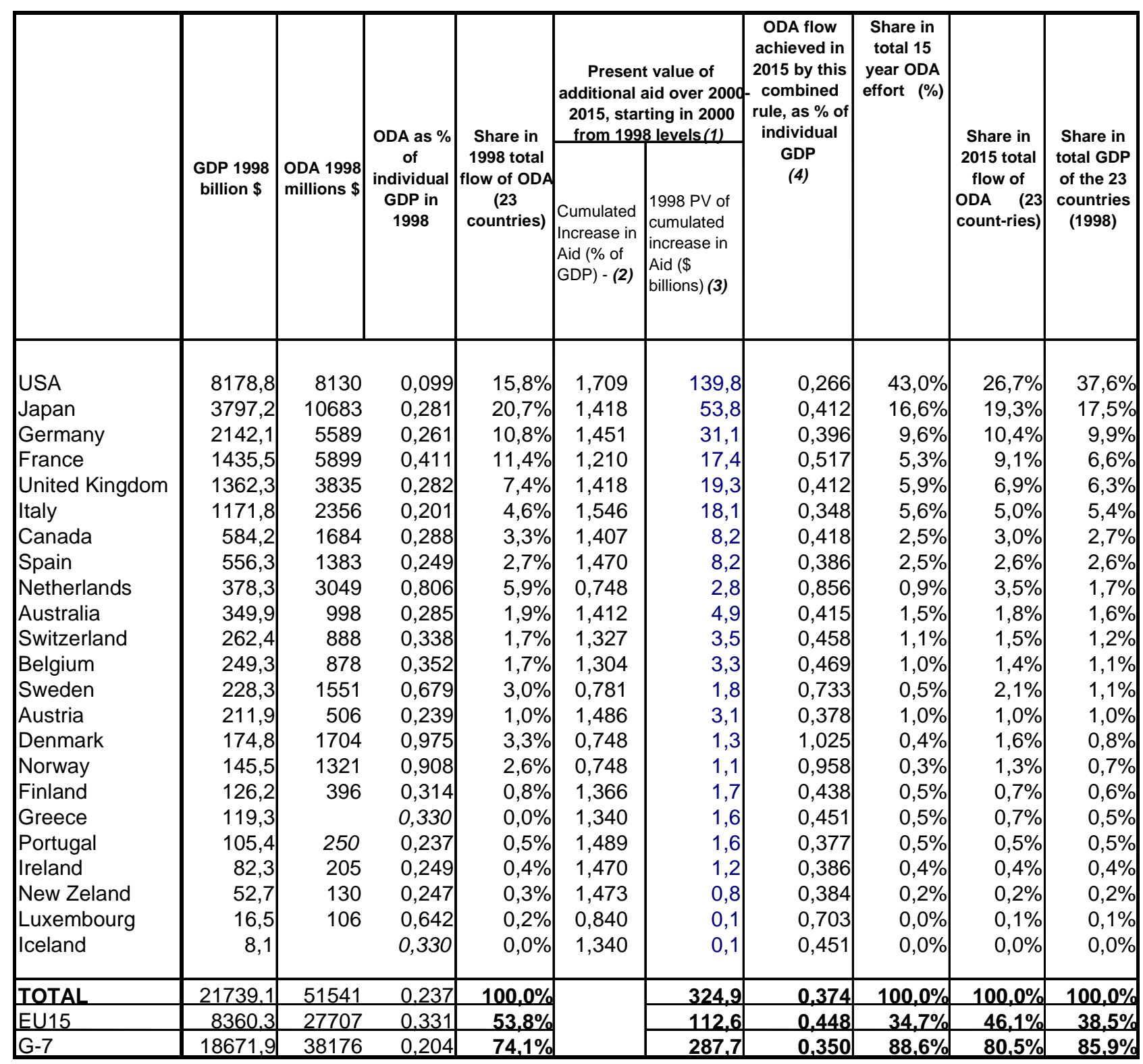

**** All data refer to 1998 (source : OCDE, Development Aid Committee 1999). ODA figures for Portugal refer to 1997. For Grece and Iceland, ODA figures not available and supposed to be equal to EU-15 average

(1) under the following hypotheses : GDP is expected to grow at a rate equal to the real interest rate ; therefore, the NPV of the additional aid flows equal the sum of each periods' increases in aid ;

$(2)=\left\{\left(0.7-A_{1998}^{j}\right)^{*}\left(15-((1-\text { gamma }) / \text { gamma })^{*}\left(1-(1-\text { gamma })^{* *} 15\right)\right)+15^{*} 0.05\right\} ;$ in \% of GDP - ${ }^{\text {Aggs }}$ is the OAD/GDP level of country $\mathrm{j}$ in 1998 (col. 3)

(3) $=$ preceding column * column 1 (GDP in 1998)

(4) $=0,05 \%$ of flat increase $+\left[0.7-\left((1 \text {-gamma })^{* *} 15\right)^{*}(0.7-\right.$ Ag98 $\left.)\right]$ of accumulated variable increase (provided $\mathrm{A}_{1998}^{\mathrm{j}}$ below $\left.0.7 \%\right)$; "totals" are GDP weighted averages 


\section{References}

Berthélémy, J.-C. and A. Vourc'h (1991), Burden-Sharing Among the Creditors of Defaulting Debtor Countries, OECD Development Centre, mimeo, May 1991.

Buiter, W. and T.N. Srinivasan (1987), "Rewarding the profligate and punishing the prudent: some recent proposals for debt relief", World Development, Vol. 15, pp.411-417.

Buiter, W., K. Kletzer and T.N. Srinivasan (1989), "Some Thoughts on the Brady Plan: Putting a Fourth Leg on the Donkey", World Development, Vol. 17, No. 10, October 1989.

Bulow, J., K. Rogoff and A. Bevilaqua (1992), "Official Creditor Seniority and Burden-Sharing in the Former Soviet Bloc", Brookings Papers on Economic Activity, No.1-1992.

Bulow, J. and K. Rogoff (1990), "Cleaning up Third World debt without getting taken to the cleaners", Journal of Economic Perspectives, vol. 4, n 1, pp. 31-42.

Claessens, S. (1990), "The Debt-Laffer Curve: Some Estimates", World Development, Vol. 18, No. 12, December 1990.

Claessens, S. , E. Detragiache, R. Kanbur and P. Wickham (1997), HIPCs' Debt. Review of the Issues, Journal of African Economies, Vol.6, No.2, pp.231-254.

Cohen, D. (1991), Private Lending to Sovereign States. A Theoretical Autopsy, M.I.T. Press, 1991.

Collier, P. \& D. Dollar (1998), Aid Effectiveness : What Works, What Doesn't and Why, mimeo, World Bank.

Collier, P. and D. Dollar (1999), Can the world cut poverty in half ? How policy reform and effective aid can meet the DAC targets, mimeo, World Bank

Drèze, J.H., A. Kervyn, J.P. Platteau and P. Reding (1991), " A proposal for cooperative relief of debt in Africa (CORDA)", chap. 12, pp. 170-197, in A. Steinherr and D. Weiserbs, Eds., Evolution of the International and Regional Monetary Systems, Macmillan, London, 1991.

Filmer, D. and L. Pritchett (1999), «The impact of public spending on health : does money matter? », Social Science and Medicine, pp.1309-1323

Foster, M., J. Healey, M. Martin \& H. White [1999], Linking HIPC II Debt Relief with Poverty Reduction and Wider Aid Issues : Some Reflections and Suggestions, ODI, Paper presented at the HIPC Review Seminar, Addis Ababa, July 1999.

IMF and IDA (1999a), "Heavily Indebted Poor Countries (HIPC) Initiative perspectives on the current framework and options for change", mimeo, Washington. 
IMF and IDA (1999b), "Poverty Reduction Strategy Papers-Operational Issues", mimeo, Washington, December 10.

Krugman, P. (1988), "Financing versus Forgiving a Debt Overhang", Journal of Development Economics, Vol. 29, No. 1/2, November 1988.

Northover, H., K. Joyner and D. Woodward (1998), "A human development approach to debt sustainability for the world's poor", mimeo, CAFOD, London.

OCDE/DAC (1996), "Shaping the 21st Century: The Contribution of Development Cooperation", mimeo, Paris.

OCDE/DAC (1999), "Financial flows to Developing Countries in 1998", News Release www.ocde.org), Paris, June

Raffer, K. (1990), Applying Chapter 9 Insolvency to International Debt: An Economically Efficient Solution with a Human Face, World Development, Vol.18, pp.301-311.

Sachs, J. (1989), "The Debt Overhang of Developing Countries", in G. CALVO et al (eds), Debt, Stabilisation and Development: Essays in Memory of Carlos Diaz Alejandro, Oxford, Basic Blackwell and WIDER.

Sachs, J. (1990), "A strategy for efficient debt reduction", Journal of Economic Perpectives, vol. $4, \mathrm{n}^{\circ} 1$, pp. 19-29

Sachs, J., K. Botchwey, M. Cuchra and S. Sievers (1999), "Implementing debt relief for the HIPC's", mimeo, Centre for International Development, Harvard, Cambridge (Mass).

Smith, G. and J. Cuddington (eds.) (1985), International Debt and the Developing Countries, World Bank

United Nations Programme for Development (1999), Human Development Report 1999 ,

New York

UNDP, UNESCO, UNFPA, UNICEF, WHO, WORLD BANK (1998), Implementing the 20/20 Initiative: achieving universal access to basic social services, September, 30p.

Van Wijnbergen S. (1990), "Mexico's external debt restructuring in 1989-1990", PRE Working Paper, $\mathrm{n}^{\circ}$ 424, The World Bank, Washington.

World Bank (1999a), Global Development Finance, CD-ROM

World Bank (1999b), World Development Report 1998-1999 and World Development Indicators 1999 (CD-ROM) 
World Bank (1999c), Modifications to the Heavily Indebted Poor Countries (HIPC) Initiative, July, Washington (www.worldbank.org/html/extdr/hipc)

World Bank (1999d), « Poverty trends and Voices of the Poor », World Bank, Poverty Reduction and Economic Management and Human Development Networks and Development Economics Vice Presidency, December, 2 , 1999, mimeo, 53p.

\section{Index of acronyms}

ACP - countries : African, Caribbean and Pacific countries

CAFOD : Catholic Fund for Overseas Development

DAC : Development Aid Committee

GDP (GNP) : Gross Domestic (National) Product

HDI : Human Development Indicator

HIPC : Heavily Indebted Poor Countries

IDA : International Development Association

IMF : International Monetary Fund

NGO : Non-governmental Agency

NPV : Net Present Value

ODA : Official Development Assistance

OECD : Organisation of Economic Co-operation and Development

PPG Debt : Public or publicly guaranteed debt

TDS : Total Debt Service

UNDP : United Nations Development Programme

WHO : World Health Organisation 